\author{
Universidade de São Paulo \\ Faculdade de Medicina de Ribeirão Preto \\ Departamento de Patologia e Medicina Legal
}

VANESSA ALMEIDA AMORIN

Relação entre a expressão proteica de MT1-MMP, MMP-2 e TIMP-2 e a progressão do carcinoma papilífero de tireoide

Ribeirão Preto 


\title{
Relação entre a expressão proteica de MT1-MMP, MMP-2 e TIMP-2 e a progressão do carcinoma papilífero de tireoide
}

\author{
Versão Corrigida \\ A versão original encontra-se disponível tanto na Biblioteca da Unidade que aloja o \\ Programa, quanto na Biblioteca Digital de Teses e Dissertações da USP (BDTD). \\ Tese apresentada ao Departamento de Patologia da \\ Faculdade de Medicina de Ribeirão Preto da \\ Universidade de São Paulo para obtenção do título \\ de Doutor em Ciências. \\ Área de Concentração: Patologia Experimental \\ Orientador: Prof. Dr. Edson Garcia Soares
}

Ribeirão Preto 
Autorizo a reprodução e divulgação total ou parcial deste trabalho por qualquer meio convencional ou eletrônico, para fins de estudo e pesquisa, desde que citada a fonte.

FICHA CATALOGRÁFICA

Amorin, Vanessa Almeida.

Relação entre a expressão proteica de MT1-MMP, MMP-2 e TIMP-2 e a progressão do carcinoma papilífero de tireoide.

81p.: il.; $30 \mathrm{~cm}$

Tese de doutorado apresentada à Faculdade de Medicina de Ribeirão Preto, Universidade de São Paulo/USP. Departamento de Patologia. Área de concentração: Patologia Experimental.

Orientador: Soares, Edson Garcia

1. Carcinoma papilífero da tireoide. 2. Metástase linfonodal. 3. Matriz extracelular. 4. Metaloproteinases. 5. Imunoistoquímica. 6. Fatores clínicos. 
Nome: Amorin, Vanessa Almeida

Título: Relação entre a expressão proteica de MT1-MMP, MMP-2 e TIMP-2 e a progressão do carcinoma papilífero de tireoide.

Tese de Doutorado apresentada a Faculdade de Medicina de Ribeirão Preto da Universidade de São Paulo para obtenção do título de Doutor em Ciências. Área de concentração: Patologia. Curso: Patologia Experimental.

\section{Banca Examinadora}

Prof.Dr.

Instituição:

Assinatura:

Prof. Dr.

Instituição:

Assinatura:

Prof. Dr.

Instituição:

Assinatura:

Prof. Dr.

Instituição:

Assinatura: 
Dedico esse trabalho aos meus amados pais, pela confiança e apoio incondicional aos meus estudos. Para que saibam que o meu amor e admiração por vocês é infinito. 


\section{Agradecimento Especial}

Ao meu orientador Prof. Dr Edson Garcia Soares,

Minha eterna gratidão pela confiança depositada em mim, por me acolher no laboratório e pela dedicação. Agradeço também pelos ensinamentos e por contribuir

na minha formação profissional. 


\section{Agradecimentos}

A Deus, meu bem mais precioso. Por ter colocado pessoas tão especiais ao meu lado e por me guiar em momentos difíceis e de dúvidas.

À banca examinadora pela presença e disposição para avaliar esse trabalho.

À Profa. Dra. Simone Gusmão Ramos, pelo apoio sempre que precisei.

Às técnicas do Departamento de Patologia da Faculdade de Medicina de Ribeirão Preto - USP: Ana Maria da Rocha e Elaine Medeiros Floriano, pela dedicação e pelos ensinamentos sobre as técnicas que tanto contribuíram para o enriquecimento de meu conhecimento, por me ajudarem em todos os momentos em que precisei.

Às minhas colegas do departamento: Maria José Figueiredo, Andressa Duarte e Patrícia dos Santos Leão, por me ajudarem em toda a minha jornada até aqui, pela convivência, amizade e troca de experiências.

À minha companheira de laboratório, Janaína Regina Léllis, por todos os momentos de alegrias e tristezas que passamos juntas, pelas risadas e reflexões durante esses anos de trabalho.

Às secretárias do Departamento de Patologia Neide T. Gonçalves, Rosângela N. Paiva, Camila L. Zambonini, ao técnico de informática Felipe D. Coelho, pela convivência, por toda a dedicação e gentileza.

A toda minha família, em especial a minha irmã Vitória Almeida Amorin e ao meu primo Samuel Amorin Grisote, pelo carinho, cumplicidade e por serem parte essencial da minha vida.

A todos os meus amigos, por todo o apoio, por me ouvirem sempre que precisei, pelos abraços e palavras consoladoras. "Amizade só faz sentido se traz o céu mais perto de você e se inaugura aqui mesmo o seu começo"

À CAPES e CNPq, pelo apoio financeiro a pesquisa.

Enfim, a todos que de alguma forma contribuíram para a realização desse trabalho. Muito obrigada! 
"A vitória persegue aqueles que nunca desistem, acompanha os que persistem em sonhar e permanece com os que aprenderam a multiplicá-la." 


\section{RESUMO}

\section{Amorin, VA. Relação entre a expressão proteica de MT1-MMP, MMP-2 e TIMP-2 e}

a progressão do carcinoma papilífero da tireoide. Tese. Faculdade de Medicina de Ribeirão Preto, Universidade de São Paulo, Ribeirão Preto, 2020.

O câncer de tireoide é a neoplasia endócrina mais prevalente e sua incidência aumentou nas últimas três décadas em todo o mundo. Sabe-se que o crescimento e a proliferação de células cancerígenas são amplamente influenciados por sua interação mecânica com o microambiente. Assim, as metaloproteinases da matriz (MMPs) interferem fisicamente na matriz extracelular (MEC) circundante para permitir a migração celular e o desenvolvimento do tumor, sendo que o complexo ternário MT1-MMP/ MMP-2/ TIMP-2 tem demonstrado ter grande participação nesse mecanismo. Este estudo teve como objetivo investigar a expressão imunoistoquímica da MT1-MMP, MMP-2 e TIMP-2 no carcinoma papilífero da tireoide (CPT) e correlacionar os achados com os parâmetros clínico-patológicos e com a progressão tumoral. Os pacientes com CPT foram divididos em: CPT sem metástase (CPTS), CPT com metástase (CPTM) e metástase linfonodal cervical $(\mathrm{ML})$. Também foi realizada análise morfométrica dos colágenos tipo I e III em tumores primários de CPT. O CPT apresentou um aumento da expressão de MT1MMP, MMP-2 e TIMP-2 quando comparadas com o tecido normal. A protease MT1MMP mostrou-se positiva em 82,6\% dos casos de CPTM e em 60\% no CPTS, sendo que na $M L$ houve um aumento da expressão moderada e intensa (34,7\%). A expressão de MT1-MMP foi correlacionada com o estadio da doença $(p=0,02)$ e idade $(p=0,01)$. A MMP-2 mostrou-se positiva em 60\% dos casos de CPTM e em 80\% no CPTS, com predomínio de marcação leve, porém na ML houve um aumento da marcação moderada e intensa (48\%). Todos os casos apresentaram marcação positiva para o TIMP-2 e a marcação predominante foi a intensa nos grupos CPTM e ML, e moderada no grupo CPTS (80\%). O colágeno tipo I diminuiu no CPTS e CPTM. A expressão concomitante de MT1-MMP, MMP-2 e TIMP-2 foi vista em 48\% dos pacientes com CPTM, 52\% no grupo ML e em $40 \%$ no grupo CPTS. Embora nem todos os pacientes que evoluíram para a metástase possuíam expressão concomitante dessas proteínas em células malignas, a MT1-MMP foi correlacionada 
com o alto estadio (III e IV) e idade acima de 45 anos no CPT. Houve uma diminuição do colágeno tipo I no CPT quando comparados com tecido tireoidiano saudável, que é característico do remodelamento da MEC nos estágios iniciais da doença.

Palavras-chave: carcinoma papilífero de tireoide, metástase linfonodal, matriz extracelular, metaloproteinases, imunoistoquímica, fatores clínicos. 


\begin{abstract}
Amorin, VA. Relationship between MT1-MMP, MMP-2 and TIMP-2 protein expression and the progression of papillary thyroid carcinoma. Thesis. Faculty of Medicine of Ribeirão Preto, University of São Paulo, Ribeirão Preto, 2020.
\end{abstract}

Thyroid cancer is a more prevalent endocrine neoplasia and its increase in the last three decades worldwide. It is known that the growth and proliferation of cancer cells are largely influenced by their mechanical interaction with the microenvironment. Thus, matrix metalloproteinases (MMPs) physically interfere with the surrounding extracellular matrix to allow cell migration and tumor development. The MT1-MMP/ MMP-2/ TIMP-2 ternary complex has been shown to play a major role in this mechanism. This study aimed to investigate the immunohistochemical expression of MT1-MMP, MMP-2 and TIMP-2 in papillary thyroid carcinoma (PTC) and to correlate the findings with clinical pathological parameters and tumor progression. PTC patients were divided into: PTC without metastasis (CPTS), PTC with metastasis (CPTM) and cervical lymph node metastasis (ML). Morphometric analysis of collagen types I and III in primary PTC tumors was also performed. PTC showed an increased expression of MT1-MMP, MMP-2 and TIMP-2 when compared to normal tissue. The MT1-MMP protease was positive in $82.6 \%$ of CPTM cases and in $60 \%$ without CPTS, whereas in $\mathrm{ML}$ there was an increase in moderate and intense expression (34.7\%). MT1-MMP expression was correlated with the stage of the disease $(p=0.02)$ and age $(p=0.01)$. MMP-2 was positive in $60 \%$ of CPTM and $80 \%$ in CPTS, with a predominance of weak marking, but in $\mathrm{ML}$ there was an increase in moderate to intense marking (48\%). All cases showed positive expression for TIMP-2 and the predominant marking was intense in the CPTM and ML group, and moderate in the CPTS group (80\%). Type I collagen decreased in CPTS and CPTM. Concomitant expression of MT1-MMP, MMP-2 and TIMP-2 was seen in $48 \%$ of patients with CPTM, 52\% in the ML group and $40 \%$ in the CPTS group. Although not all patients who progressed to metastasis had concomitant expression of these proteins in malignant cells, MT1-MMP was correlated with high stage (III and IV) and age over 45 years on CPT. There was a decrease in type I collagen in CPT when compared to 
healthy thyroid tissue, which is characteristic of ECM remodeling in the early stages of the disease.

Keywords: papillary thyroid carcinoma, lymph node metastasis, extracellular matrix, metalloproteinases, immunohistochemistry, clinical factors. 


\section{LISTA DE ABREVIATURAS E SIGLAS}

AJCC

ATA

CAT

CPT

CTF

DAB

FMRP

HC

HE

MEC

MMP

MT-MMP

TIMP

TNM

UICC
American Joint Committee on Cancer

Associação Americana de Tireoide

Carcinoma anaplásico da tireoide

Carcinoma papilífero da tireoide

Carcinoma folicular da tireoide

Diaminobenzidine

Faculdade de Medicina de Ribeirão Preto

Hospital das Clínicas

Hematoxilina- Eosina

Matriz extracelular

Metaloproteinases da matriz

Metaloproteinases da matriz do tipo membrana

Inibidor tecidual de metaloproteinases

Tumor Nódulo Metástase

União Internacional para o Controle do Câncer 


\section{LISTA DE TABELAS}

Tabela 1: Classificação das MMPs em relação aos seus substratos. .25

Tabela 2: Descrição dos anticorpos utilizados na reação de imunoistoquímica. ......34

Tabela 3: Características clínico-patológicas dos casos do estudo. 38

Tabela 4: Comparação entre a expressão de MT1-MMP e os parâmetros clínicopatológicos do CPT. 40

Tabela 5: Comparação entre a expressão de MMP-2 e os parâmetros clínicopatológicos do CPT.

Tabela 6: Comparação entre a expressão de TIMP-2 e os parâmetros clínicopatológicos do CPT. 44

Tabela 7: Distribuição da expressão imunoistoquimica da MT1-MMP nos diferentes grupos. .45

Tabela 8: Distribuição da expressão imunoistoquimica da MMP-2 nos diferentes grupos. 48

Tabela 9: Distribuição da expressão imunoistoquimica do TIMP-2 nos diferentes grupos.

Tabela 10: Análise da correlação entre a expressão concomitante dos marcadores e a progressão tumoral do carcinoma papilífero da tireoide. .55

Tabela 11: Comparação da expressão de colágeno tipo I nos diferentes grupos. ...56 Tabela 12: Análise da matriz colagênica (colágeno tipo I e III) nos diferentes grupos. 


\section{LISTA DE FIGURAS}

Figura 1: Representação esquemática da estrutura das Metaloproteinases de Matriz (MMPs). As MMPs possuem três domínios distintos: pró-peptídeo N-terminal com peptídeo sinal, domínio catalítico (zona de ligação ao zinco) e extremidade Cterminal (adaptado de Geurts et al, 2012). 26

Figura 2: Ativação do pro-MMP-2 pela MT1-MMP na superfície celular (Fonte: Gifford; Itoh, 2019). .28

Figura 3: Fotomicrografias da expressão imunoinstoquímica da MT1-MMP(100 $\mu \mathrm{m})$.A. Expressão negativa da MT1-MMP em tecido tireoidiano saudável, B. Marcação citoplasmática positiva de intensidade leve da MT1-MMP em células foliculares da tireoide no grupo CPTS, C. Marcação citoplasmática positiva de intensidade leve da MT1-MMP em células foliculares da tireoide no grupo CPTM...46 Figura 4: Fotomicrografias da expressão imunoinstoquímica da MT1-MMP de intensidade moderada no citoplasma de células metastáticas no linfonodo ( $A: 200$ $\mu \mathrm{m}, \mathrm{B}: 100 \mu \mathrm{m})$.

Figura 5: Fotomicrografias da expressão imunoinstoquímica da MMP-2 (100 $\mu \mathrm{m})$. A. Expressão negativa da MMP-2 em tecido tireoidiano saudável, B. Marcação citoplasmática positiva de intensidade moderada da MMP-2 em células foliculares da tireoide no grupo CPTS, C. Marcação citoplasmática positiva de intensidade moderada da MMP-2 em células foliculares da tireoide no grupo CPTM.

Figura 6: Fotomicrografias da expressão imunoinstoquímica da MMP-2 com intensidade moderada no citoplasma de células metastáticas no linfonodo ( $A: 200$ $\mu \mathrm{m}, \mathrm{B}: 100 \mu \mathrm{m})$.

Figura 7: Fotomicrografias da expressão imunoinstoquímica do TIMP-2 (100 $\mu \mathrm{m})$. A. Expressão negativa do TIMP-2 em tecido tireoidiano saudável, B. Marcação citoplasmática positiva com intensidade moderada do TIMP-2 em células foliculares da tireoide no grupo CPTS, C. Marcação citoplasmática positiva intensa do TIMP-2 em células foliculares da tireoide no grupo CPTM.

Figura 8: Fotomicrografias da expressão imunoinstoquímica com intensidade moderada do TIMP-2 no citoplasma de células metastáticas no linfonodo (A: $200 \mu \mathrm{m}$, B: $100 \mu \mathrm{m})$. 
Figura 9: Fotomicrografias das fibras colágenas, evidenciando, em vermelho, o colágeno tipo I e, em verde, o colágeno tipo III $(50 \mu \mathrm{m})$. A e D: Tecido tireoidiano saudável, B e E: Grupo CPTS, C e F: Grupo CPTM. No painel do lado esquerdo $(A, B, C)$, observam-se cortes histológicos corados com Picrosirius Red e do lado direito $(D, E, F)$, os mesmos cortes, porém sob microscopia de luz polarizada. ........58 


\section{SUMÁRIO}

1 INTRODUÇÃO

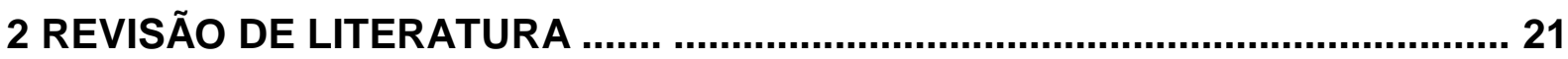

2.1 Matriz extracelular: estrutura e função ……….......................................... 21

2.2 A matriz extracelular no câncer: metástase .................................................. 22

2.3 Metaloproteinases da matriz: estrutura, função e inibidores.............................. 24

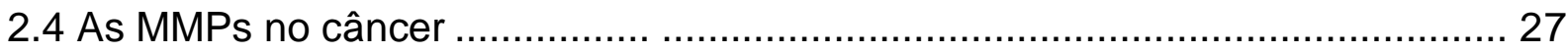

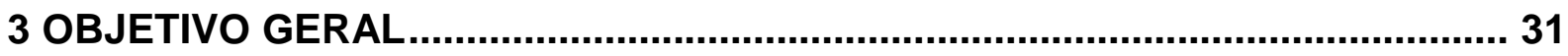

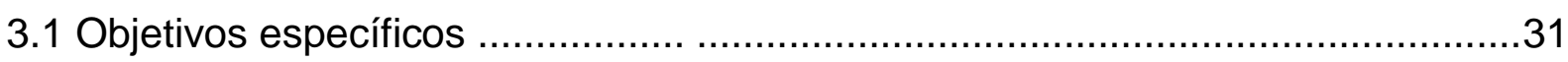

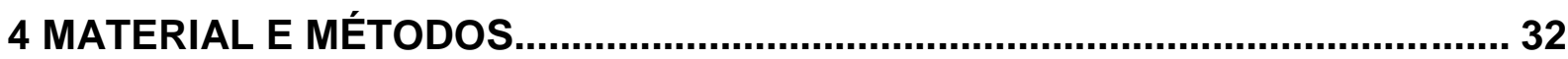

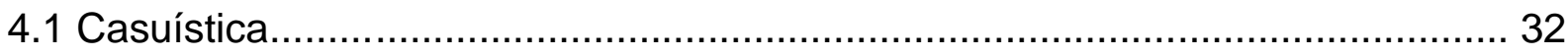

4.2 Reações de imunoistoquímica .................................................................. 33

4.3 Análise dos marcadores MT1-MMP, MMP-2, TIMP-2 ….............................. 34

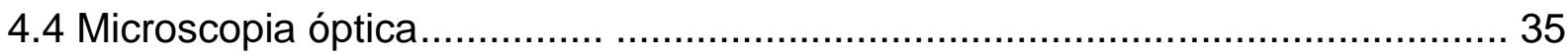

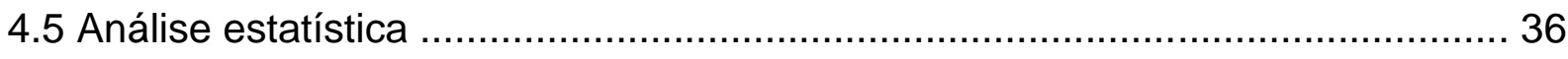

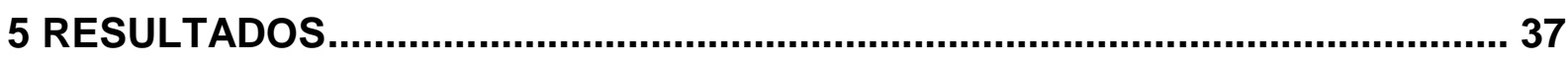

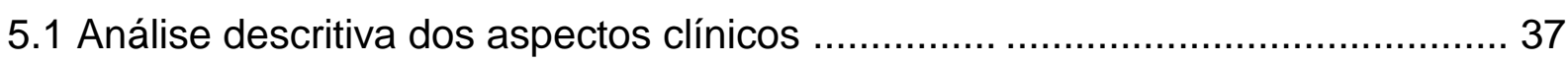

5.2 Associação da expressão imunoistoquímica de MT1-MMP, MMP-2 e TIMP-2 com

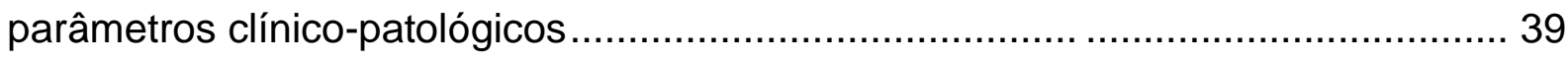

5.3 Análise imunoistoquímica dos marcadores MT1-MMP, MMP-2 e TIMP-2 ......... 45

5.4 Análise da expressão concomitante dos marcadores ..................................... 54

5.5 Análise da matriz colagênica.................................................................. 56

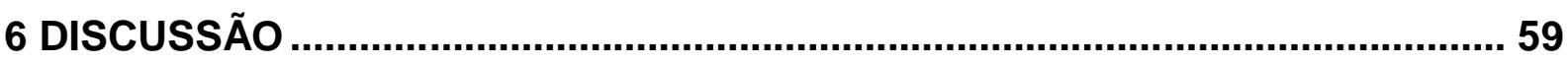

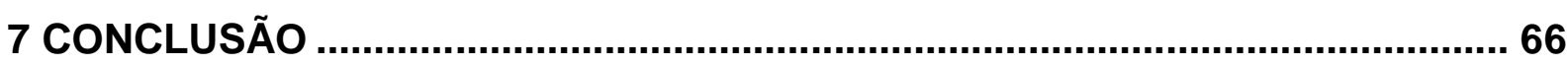

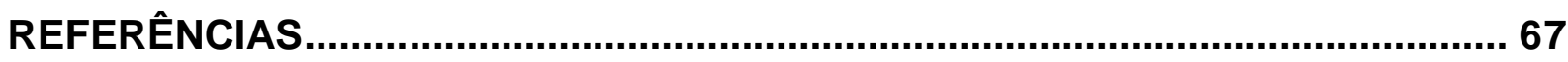

ANEXOS 


\section{INTRODUÇÃO}

O câncer de tireoide é a neoplasia endócrina mais prevalente e sua incidência aumentou nas últimas três décadas em todo o mundo. Se as tendências recentes forem mantidas, o câncer de tireoide pode se tornar o quarto câncer mais comum até 2030 nos Estados Unidos (LA VECCHIA et al., 2015; RAJABI et al., 2019). No Brasil, as estimativas apontam que haverá 13.780 novos casos, sendo 1.830 homens e 11.950 mulheres, com 748 mortes (239 homens e 509 mulheres). Além disso, é o quinto tumor mais frequente em mulheres nas regiões Sudeste e Nordeste, desconsiderando o câncer de pele não melanoma. Os carcinomas diferenciados são os tipos mais frequentes, sendo eles: o papilífero (entre $50 \%$ e $80 \%$ dos casos), o folicular (de $15 \%$ a $20 \%$ dos casos) e o de células de Hürthle (menos que $5 \%$ ). Existem ainda os carcinomas pouco diferenciados (cerca de $10 \%$ dos casos) e os indiferenciados (também cerca de 10\%) (INCA, MS, 2018).

De acordo com a origem celular, o câncer de tireoide é classificado em 2 tipos histológicos principais. As células parafoliculares ou C têm uma função neuroendócrina, produzem e secretam o hormônio calcitonina e originam 0 carcinoma medular da tireoide. Porém, a maioria das neoplasias ocorre nas células foliculares, responsáveis pela síntese do hormônio tireoidiano. Os tumores derivados de células foliculares podem ser divididos em três formas patológicas principais: carcinoma papilífero da tireoide (CPT), carcinoma folicular da tireoide (CTF) e carcinoma anaplásico da tireoide (CAT) (VALVO; NUCERA, 2019). O carcinoma anaplásico da tireoide ou carcinoma indiferenciado da tireoide é um tumor agressivo raro, que perde as características biológicas das células foliculares originais, como captação de iodo e síntese de tireoglobulina e o prognóstico é quase sempre fatal (CHIACCHIO et al., 2008). No entanto, a maioria dos carcinomas da tireoide apresenta um crescimento lento e um bom prognóstico com taxas de sobrevida a longo prazo (95\% aos 20 anos), embora o risco de mortalidade por doenças recorrentes ou persistentes ainda seja alto (SHAKIB et al., 2019).

O CPT é o tipo mais comum de carcinoma bem diferenciado da tireoide, constituindo $81,2 \%$ de todas as malignidades da tireoide (CHA et al., 2000). As taxas de sobrevida relatadas para lesões não metastáticas são de $97,8 \%$ em cinco anos e 
94,9\% em 10 anos. Geralmente, o CPT é detectado entre a terceira e quinta décadas de vida dos pacientes com idade média de 40 anos. A incidência de CPT aumenta com a idade e as mulheres são mais frequentemente afetadas que os homens, em proporções de 2:1 a 4:1 (LUO et al., 2017). Apesar de ter curso geralmente favorável, com sobrevida em 10 anos superior a $90 \%$, estudos relatam uma taxa de recorrência de 8 a 23\% após o tratamento inicial da operação (GUO; WANG, 2014).

No aspecto microscópico, o CPT convencional (clássico) é caracterizado pela arquitetura papilar e características nucleares típicas como cromatina fina e regularmente dispersa (aspecto de vidro fosco), pseudoinclusões e fendas na membrana nuclear. Porém, uma proporção significativa de CPT exibe uma variedade de características morfológicas que diferem do convencional. O CPT possui 15 variantes histológicas identificadas, sendo as de melhor prognóstico a clássica e a folicular. Algumas variantes, incluindo as de célula alta, célula colunar, hobnail, esclerosante difusa e sólida, estão associadas a um comportamento mais agressivo do que o CPT clássico. O CPT clássico é o mais comum (70 a 80\%), seguido da variante folicular. Já o microcarcinoma corresponde ao CPT com tamanho inferior a $1 \mathrm{~cm}$ (PUSZTASZERI; AUGER, 2017). No entanto, o prognóstico desses tumores está mais relacionado ao estágio clínico do que à própria variante, pois tumores encapsulados ou pequenos apresentam melhor prognóstico (SHI et al., 2016).

Com isso, fatores como presença ou ausência e grau de invasão vascular, multifocalidade, número e tamanho de linfonodos cervicais com metástases e presença ou não de invasão capsular foram incorporados no sistema de classificação de risco de recorrência publicados pela Associação Americana de Tireoide (ATA) (HAUGEN et al., 2016). O sistema de estadiamento preconizado pela União Internacional para o Controle do Câncer (UICC) é denominado Sistema TNM de Classificação dos Tumores Malignos. Esse sistema baseia-se na extensão anatômica da doença, levando em conta as características do tumor primário $(T)$, descreve se existe disseminação da doença para os linfonodos regionais $(\mathrm{N})$, e a presença ou ausência de metástases à distância $(M)$. Estes parâmetros recebem graduações, geralmente de T0 a T4, de N0 a N3 e de M0 a M1, respectivamente 
(BARBOSA et al., 2017). Assim, os fatores de mau prognóstico do CPT incluem idade avançada no diagnóstico, sexo masculino, tumor de grande tamanho e crescimento extratireoidiano. A cirurgia geralmente é a terapia indicada para o CPT, sendo que a extensão da cirurgia depende do tamanho do tumor primário e da ausência ou presença de metástases em linfonodos (ABDULLAH et al., 2019).

Embora o câncer seja uma doença multifatorial, está bem estabelecido que alterações genéticas, epigenéticas e fatores ambientais são a base da carcinogênese, e esses fatores desempenham papéis fundamentais na patogênese e/ou progressão dos vários tipos de câncer humano, incluindo o câncer de tireoide (MURUGAN; MUNIRAJAN; ALZAHRANI, 2018). No CPT, fatores ambientais, em especial a deficiência de iodo, têm importante papel na patogênese desse tumor. Outros fatores, como a radioterapia externa na infância e adolescência, exposição à radiação ionizante, doença tireoidiana preexistente e fatores genéticos, entre eles mutação de RAS, proteína ERK e rearranjos do RET/ PTC estão associados com o aumento do desenvolvimento do carcinoma papilífero (INCA, MS, 2018; VALVO; NUCERA, 2019). Sabe-se também que o crescimento e a proliferação de células cancerígenas são amplamente influenciados por sua interação mecânica com o microambiente (HUANG et al., 2019). Com isso, estudos mostram que a matriz extracelular (MEC) é a principal barreira às metástases tumorais. Quando o tumor rompe a membrana basal e entra na MEC, é o início da metástase e invasão do tumor (WALKER; MOJARES; DEL RIO HERNANDEZ, 2018). Semelhante a outros carcinomas, o CPT é caracterizado principalmente por efeitos biológicos, como a destruição da MEC e das membranas basais. Assim, pequenas alterações na homeostase do microambiente podem ter efeitos significativos na proliferação de células cancerígenas. O colágeno, como o componente mais significativo da MEC, determina as propriedades funcionais primárias da matriz e alterações na deposição ou degradação desta proteína podem levar à perda da homeostase da MEC (BONNANS; CHOU; WERB, 2014).

A degradação da MEC envolve diferentes tipos de proteases, porém as principais são as metaloproteinase da matriz (MMPs). As MMPs desempenham um papel central em praticamente todos os principais estágios da progressão tumoral: invasividade e migração de células tumorais, escape da apoptose e do sistema 
imunológico, metástase e angiogênese (JABŁOŃSKA-TRYPUĆ; MATEJCZYK; ROSOCHACKI, 2016). Assim, as MMPs interferem fisicamente na MEC circundante para permitir a migração celular, como também criam um microambiente propício ao desenvolvimento do tumor por meio da liberação do fator de crescimento e exposição de sítios de ligação no local (WALKER; MOJARES; DEL RíO HERNÁNDEZ, 2018). Algumas metaloproteinases da matriz (MMPs) são anormalmente expressas no CPT e podem ser usadas como marcadores de diagnóstico (ZHANG et al., 2018). Em carcinomas papilíferos da tireoide, a ativação de MMP-2 e a expressão de MT1-MMP parecem estar correlacionadas com a presença de metástases linfonodais (YEH et al., 2006). Nesse contexto, as informações de expressão e regulação da atividade de MMPs implicadas na progressão tumoral podem ajudar não apenas a entender melhor os mecanismos moleculares de invasão e metástases, mas também no desenvolvimento de novos medicamentos e terapia.

Com isso, discutimos o papel da matriz extracelular no carcinoma papílifero da tireoide, assim como os mecanismos que ocorrem durante a sua degradação através da ação das MMPs, favorecendo o processo de metástase, que é um dos principais fatores que influenciam no prognóstico e sobrevida dos pacientes portadores desta neoplasia. 


\section{REVISÃo DE LITERATURA}

\subsection{Matriz extracelular: estrutura e função}

A matriz extracelular (MEC) é comumente definida como o componente não celular do tecido que fornece suporte estrutural bioquímico e essencial para seus constituintes celulares. Todo órgão possui uma MEC com composição única, gerada nos estágios embrionários iniciais. Nos mamíferos, a MEC é composta por cerca de 300 proteínas que contribuem para a estrutura e função da MEC (INSUARODRÍGUEZ; OSKARSSON, 2016). A MEC consiste em uma malha de proteínas fibrosas, proteoglicanos, materiais amorfos, minerais e água. Também contém fatores de crescimento e outras citocinas que orquestram processos de desenvolvimento em morfogênese, regeneração e manutenção (ROZARIO; DESIMONE, 2010).

Existem dois tipos principais de MEC que diferem em relação à sua localização e composição: a matriz intersticial do tecido conjuntivo, que circunda as células; e a membrana basal, que é uma forma especializada de MEC que separa o epitélio do estroma circundante. A matriz intersticial envolve as células e é composta principalmente de colágeno I e fibronectina, que fornecem andaimes estruturais para os tecidos. Por outro lado, a membrana basal é mais compacta que a matriz intersticial e consiste principalmente de colágeno IV, lamininas, proteoglicanos e outras proteínas, como nidogênio e entactina, sintetizadas e secretadas pelas células epiteliais e células endoteliais (BONNANS; CHOU; WERB, 2014; LU; WEAVER; WERB, 2012). Os colágenos são as principais proteínas estruturais da MEC e são classificados em formas fibrilares (colágenos I - III, V e XI) e não fibrilares. As fibrilas de colágeno fornecem resistência à tração para a MEC, limitando a distensibilidade dos tecidos (BONNANS; CHOU; WERB, 2014).

Além de proporcionar suporte estrutural e manter a arquitetura dos tecidos, a MEC também é um componente fisiologicamente ativo do tecido, responsável pela comunicação célula-célula, adesão celular, polaridade, migração, diferenciação, sobrevivência e proliferação celular (WALKER; MOJARES; DEL RÍO HERNÁNDEZ, 2018). Não é de surpreender que doenças como câncer, definidas por homeostase 
tecidual interrompida e perda de um fenótipo diferenciado, sejam acompanhadas de alterações na composição, organização e propriedades mecânicas da MEC que contribuem não apenas para a transformação maligna, mas também para a progressão e metástase do tumor (KAI; DRAIN; WEAVER, 2019).

\subsection{A matriz extracelular no câncer: metástase}

Os tumores podem ser definidos como uma perda de organização do tecido e comportamento aberrante de alguns tipos celulares que, crescendo independentemente do tecido circundante, induzem alterações na MEC (PAOLILLO; SCHINELLI, 2019). A matriz extracelular regula o desenvolvimento e a homeostase do tecido, e sua desregulação contribui para a progressão neoplásica. Foi observado que mesmo na massa primária do tumor, a MEC é alterada qualitativa e quantitativamente de maneira permissiva, promovendo a progressão do tumor e influenciando a invasão de células cancerígenas (EBLE; NILAND, 2019).

O remodelamento da MEC durante o desenvolvimento e a homeostase dos tecidos e em doenças patológicas leva a uma reorganização de sinais bioquímicos e biomecânicos apresentados à célula (MALIK; LELKES; CUKIERMAN, 2015). Em tumores sólidos, as alterações normalmente incluem superexpressão e subexpressão de moléculas de MEC; degradação aumentada e diminuída e/ou modificação pós-traducional; perda completa e até mesmo síntese de novas moléculas. Mesmo pequenas mudanças podem causar alterações significativas nas propriedades da MEC do tecido tumoral (STAMENKOVIC, 2000; WALKER; MOJARES; DEL RÍO HERNÁNDEZ, 2018).

Apenas uma pequena fração das células tumorais primárias são potencialmente capazes de formar metástases, essas células devem ter propriedades necessárias para o desprendimento da massa tumoral primária, migração em direção aos vasos sanguíneos/ linfáticos, rompimento da membrana basal, penetração do lúmenvascular, evasão da vigilância imunológica, adesão ao endotélio vascular de órgãos distais ao do sítio primário, extravasamento e sobrevivência e crescimento no microambiente invadido (CELIÀ-TERRASSA; KANG, 2016; STAMENKOVIC, 2000). 
Para isso, várias vias regulatórias são alteradas ou expressas de forma aberrante para que as células tumorais tenham capacidade de realizar todas e cada uma das etapas do processo metastático (DERYUGINA; QUIGLEY, 2006).

Além disso, para que a metástase ocorra é necessário o rompimento de várias barreiras de tecidos dotadas de colágeno (STAMENKOVIC, 2000). O principal componente das membranas basais é o colágeno tipo IV, com componentes adicionais de laminina, entactina e perlecano. A partir disso, segue-se que as células tumorais que possuem a capacidade de degradar os componentes das membranas basais podem ser capazes de atravessá-las mais rapidamente $\mathrm{e}$, consequentemente, têm uma capacidade aprimorada de formar uma metástase (MACDOUGALL; MATRISIAN, 1995). Conforme revelado por exames histológicos, a observação de defeitos na membrana basal nas proximidades de tumores malignos apoia a noção de que as células tumorais malignas produzem uma maquinaria proteolítica capaz de superar as barreiras naturais à invasão (STAMENKOVIC, 2000).

Foi estabelecido que a invasão do câncer de tireoide está associada a processos multifásicos, sendo uma delas a transição epitelial-mesenquimal (VASKO et al., 2007). Durante a transição epitelial-mesenquimal, as células epiteliais se desdiferenciam, começam a perder as restrições estruturais fornecidas pela arquitetura do tecido e passam a ter aparência fusiforme, que está relacionada ao rearranjo do citoesqueleto (VOULGARI; PINTZAS, 2009). Essas células induzem a digestão proteolítica dos receptores implicados no contato célula-célula, aumentam a atividade das moléculas de adesão que contribuem no movimento celular e estimulam proteases na superfície celular, levando a uma digestão aumentada dos constituintes da MEC (SARKAR et al., 2013). A atividade das metaloproteinases da matriz (MMPs) parece estar altamente aumentada durante a transição epitelialmesenquimal. Essas enzimas são responsáveis pela degradação da MEC e, portanto, pelo aumento da mobilidade das células mesenquimais, necessárias para invasão e metástase (CAO et al., 2008).

Existem quatro classes principais de proteases envolvidas na degradação proteolítica da matriz extracelular: seriproteases, aspartilproteases, cisteinoproteases, sendo uma das mais importantes a grande família das 
metaloproteinases (MCDONNELL; FINGLETON, 1993; VERMA; DIXIT; PANDEY, 2016). Com base em evidências recentes, além das MMPs possuírem um importante papel na invasão através da proteólise da MEC, também são capazes de reorganizá-la para se adequar à migração de células tumorais (GIFFORD; ITOH, 2019; NABESHIMA et al., 2002). Com isso, seus níveis de expressão e atividade enzimática são correlacionados a um comportamento tumoral mais agressivo em diferentes cânceres humanos e, consequentemente, um pior prognóstico (DUFFY; MCCARTHY, 1998; ROY et al., 2020).

\subsection{Metaloproteinases da matriz: estrutura, função e inibidores}

As MMPs são membros de uma família de endopeptidases de zinco que contribuem para a degradação da MEC em processos como expansão tumoral, angiogênese e remodelamento cardíaco (CUI; HU; KHALIL, 2017; JANICKI et al., 2004; MANSO et al., 2006). São capazes de digerir a MEC e as proteínas da membrana basal, mas estes não são seus únicos alvos, pois também são capazes de clivar outras MMPs, uma série de outras proteases e inibidores de protease, fatores de crescimento, quimiocinas, citocinas, receptores de superfície celular e moléculas de adesão (ITOH, 2015; MANSO et al., 2006). Vinte e cinco MMPs foram identificadas em diferentes vertebrados, das quais 22 são encontradas em humanos. Além disso, as MMPs podem ser segregadas em dois grupos: o tipo solúvel, que é liberado no espaço pericelular, e as ancoradas na membrana plasmática, as MMPs do tipo membrana (MT-MMPs) (STERNLICHT; WERB, 2001).

Além disso, as MMPs são classificadas em seis categorias distintas com base em seus substratos alvo e estrutura: colagenases, estromelisinas, matrilisinas, gelatinases, metaloproteinases tipo membrana (MT-MMPs), e outras MMPs (Tabela 1). As MMPs possuem três domínios distintos: pró-peptídeo N-terminal com peptídeo sinal, domínio catalítico (zona de ligação ao zinco) e extremidade C-terminal (Figura 1) (JABŁOŃSKA-TRYPUĆ; MATEJCZYK; ROSOCHACKI, 2016; LEE; MURPHY, 2004). Estas proteases são sintetizadas e secretadas como pró-forma latente (zimogênios) e sua atividade depende da ativação proteolítica (CUI; HU; KHALIL, 
2017). As MMPs são reguladas em diferentes níveis, incluindo expressão de mRNA, modificação pós-traducional e estimulação de sua atividade enzimática por vários ativadores endógenos e exógenos (LIU; KHALIL, 2017). Vários fatores como angiotensina II, fatores de crescimento, hormônios e citocinas podem controlar a atividade destas enzimas. Além disso, o controle da atividade das MMPs nos tecidos também pode ser mediado por inibidores teciduais de metaloproteinases (TIMPs), que se ligam ao sitio de zinco das MMPs em uma proporção de 1:1, bloqueando sua atividade (LIU; KHALIL, 2017; TSURUDA; COSTELLO-BOERRIGTER; BURNETT, 2004).

Tabela 1: Classificação das MMPs em relação aos seus substratos.

\begin{tabular}{|c|c|c|}
\hline Classificação & Exemplos & Substratos \\
\hline Colagenases & MMP-1, 8, 13 e 18 & $\begin{array}{l}\text { Colágenos tipo I, II, III, V, VII, VIII, X; } \\
\text { gelatina; agrecan; fibronectina. }\end{array}$ \\
\hline \multirow[b]{2}{*}{ Gelatinases } & MMP-2 & $\begin{array}{l}\text { Gelatinas tipo I, II, III; colágenos tipo I, III, } \\
\text { IV, V,VI, VII, X; fibronectina; elastina. }\end{array}$ \\
\hline & MMP- 9 & $\begin{array}{l}\text { Gelatinas tipo I, V; colágenos tipo I, III, IV, } \\
\text { V, VII, X, XIV; entactina; agrecan; elastina; } \\
\text { fibronectina; osteonectina; plasminogênio. }\end{array}$ \\
\hline Estromelisinas & MMP-3, 10 e 11 & $\begin{array}{l}\text { Colágenos tipo III, IV, V, IX; gelatina; } \\
\text { agrecan; perlecan; decorina; laminina; } \\
\text { elastina; caseina; osteonectina; ovostatina; } \\
\text { entactina; plasminogênio. }\end{array}$ \\
\hline Matrilisinas & MMP-7 e 26 & $\begin{array}{l}\text { Elastina, fibrinogênio, fibronectina, laminina, } \\
\text { osteoctina, versican, colágeno tipo IV. }\end{array}$ \\
\hline MMPs tipo membrana & $\begin{array}{l}\text { MT1-MMP a MT6- } \\
\text { MMP }\end{array}$ & $\begin{array}{l}\text { Colágenos tipo I, II e III, fibronectina, } \\
\text { laminina, gelatinas, vitronectina, perlecan, } \\
\text { proteoglicanos e ativação de outras MMPs. }\end{array}$ \\
\hline Outras MMPs & $\begin{array}{c}\text { MMP-20, 21, 22, 23, } \\
27,28\end{array}$ & $\begin{array}{l}\text { Gelatinas, agreguinas, laminina, casepina e } \\
\text { colágeno tipo IV. }\end{array}$ \\
\hline
\end{tabular}

Fonte: Adaptado de Conlon; Murray (2019). 
Uma vez em sua forma ativa, as MMPs participam do processo fisiológico do remodelamento da MEC através da degradação de vários componentes da membrana basal, do colágeno intersticial, da fibronectina e várias proteoglicanas. Podem interagir com várias moléculas bioativas na superfície celular e nos receptores acoplados à proteína $G$ e, assim, afetar o ambiente celular e a sinalização (BONNANS; CHOU; WERB, 2014; VISSE; NAGASE, 2003). Desempenham um papel na proliferação celular, migração (adesão/ dispersão), diferenciação, angiogênese, cicatrização e reparo de tecidos. Podem também estar envolvidas na apoptose celular e na resposta inflamatória e imune (LIU; KHALIL, 2017). Esses processos biológicos ocorrem várias vezes durante o desenvolvimento normal e na organogênese, mas se não forem adequadamente equilibrados, também podem contribuir para condições patológicas prejudiciais, como câncer, progressão tumoral e invasão tecidual (CUI; HU; KHALIL, 2017).

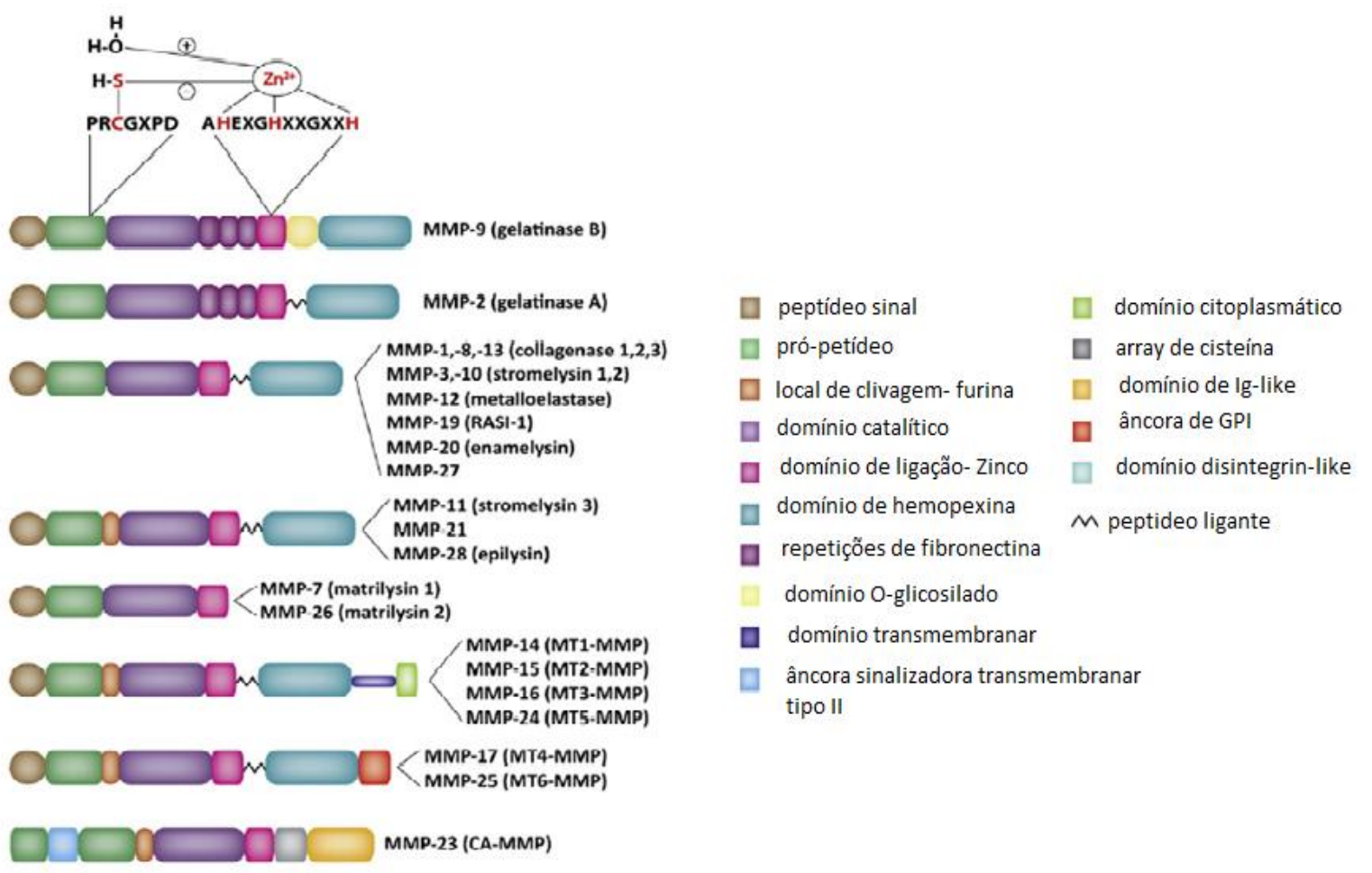

Figura 1: Representação esquemática da estrutura das Metaloproteinases de Matriz (MMPs). As MMPs possuem três domínios distintos: pró-peptídeo N-terminal com peptídeo sinal, domínio catalítico (zona de ligação ao zinco) e extremidade C-terminal (adaptado de Geurts et al, 2012). 
Os inibidores teciduais de metaloproteinases (TIMPs) são inibidores endógenos e, consequentemente, importantes reguladores da renovação da MEC, remodelamento tecidual e comportamento celular. Quatro TIMPs homólogos foram identificados e denominados TIMP-1, TIMP-2, TIMP-3 e TIMP-4 (BREW; NAGASE, 2010). Embora cada TIMP pareça capaz de inibir várias MMPs, essas proteínas exibem capacidade inibitória preferencial; por exemplo, TIMP1 e TIMP-2 inibem seletivamente MMP-9 e MMP-2, respectivamente. Os TIMPs são amplamente distribuídos em muitos tecidos e órgãos, sendo que uma alteração nos níveis de MMP ou TIMP pode alterar a proporção MMP/ TIMP e causar uma alteração na atividade específica da MMP. Os TIMPs também são essenciais para a formação de complexos não inibitórios pro-MMP/ TIMP/ MT-MMP (KALLAKURY et al., 2001; LIU; KHALIL, 2017). O aumento da expressão de TIMP foi demonstrado em uma variedade de tumores, tais como câncer de mama (JONES; GLYNN; WALKER, 1999), cancer colorretal (POWE et al., 1997), cancer gástrico (JOO et al., 2000) e câncer de pulmão (MICHAEL et al., 1999). Se a principal atividade biológica do TIMP é uma inibição de MMPs, seria esperado que níveis elevados de TIMP inibissem a invasão e metástase, melhorando assim o prognóstico (JIANG; GOLDBERG; SHI, 2002). Porém, em um estudo recente, o TIMP-2 foi considerado um fator de prognóstico ruim e relacionado com um comportamento biológico metastático em câncer gástrico (WANG et al., 2018). Devido a isso, mais estudos são necessários para elucidar o comportamento das MMPs e TIMPs na progressão tumoral.

\subsection{As MMPs no câncer}

Estudos recentes demonstraram que as metaloproteinases da matriz (MMPs) são responsáveis pela degradação da matriz extracelular (MEC) na invasão tumoral. Membros específicos da MMP não apenas aceleram a invasão de células tumorais, mas também alteram o comportamento das células tumorais e promovem a progressão do câncer (JABŁOŃSKA-TRYPUĆ; MATEJCZYK; ROSOCHACKI, 2016; LU; WEAVER; WERB, 2012). 
A MT1-MMP (ou MMP-14) foi a primeira MMP do tipo membrana descoberta e, portanto, também é referida como metaloproteinase da matriz tipo 1 da membrana (MT1-MMP). Foi sugerido que a MT1-MMP está envolvida em muitos processos biológicos, como proliferação, invasão, angiogênese e remodelamento da membrana basal. As correlações entre a expressão da MT1-MMP e as características clínicopatológicas foram exploradas em uma variedade de carcinomas humanos, como câncer de mama (TÊTU et al., 2006), câncer de pulmão (WANG et al., 2014b), câncer de esôfago (LU et al., 2019), câncer gástrico (HE et al., 2013) e câncer cervical (WANG et al., 2014a). Além disso, foi demonstrado que as MMPs ancoradas na membrana, mais notavelmente a MT1-MMP, desempenham um papel fundamental na invasão regional nos estágios iniciais da progressão do tumor (CASTRO-CASTRO et al., 2016). Isso ocorre, pois uma das funções críticas da MT1MMP é a ativação da MMP-2 e consequente aumento da proteólise da matriz extracelular. Assim, uma molécula de MT1-MMP atua como uma âncora e se liga ao TIMP-2, que recruta a pro-MMP-2 formando um complexo trimolecular: MT1-MMP/ TIMP-2/ pro-MMP-2. Uma segunda molécula MT1-MMP atua como ativador e cliva a pro-MMP-2 primeiro em sua forma intermediária $(64 \mathrm{kDa})$ e depois em sua forma totalmente ativa (62 kDa) (Figura 2) (ATKINSON et al., 1995).

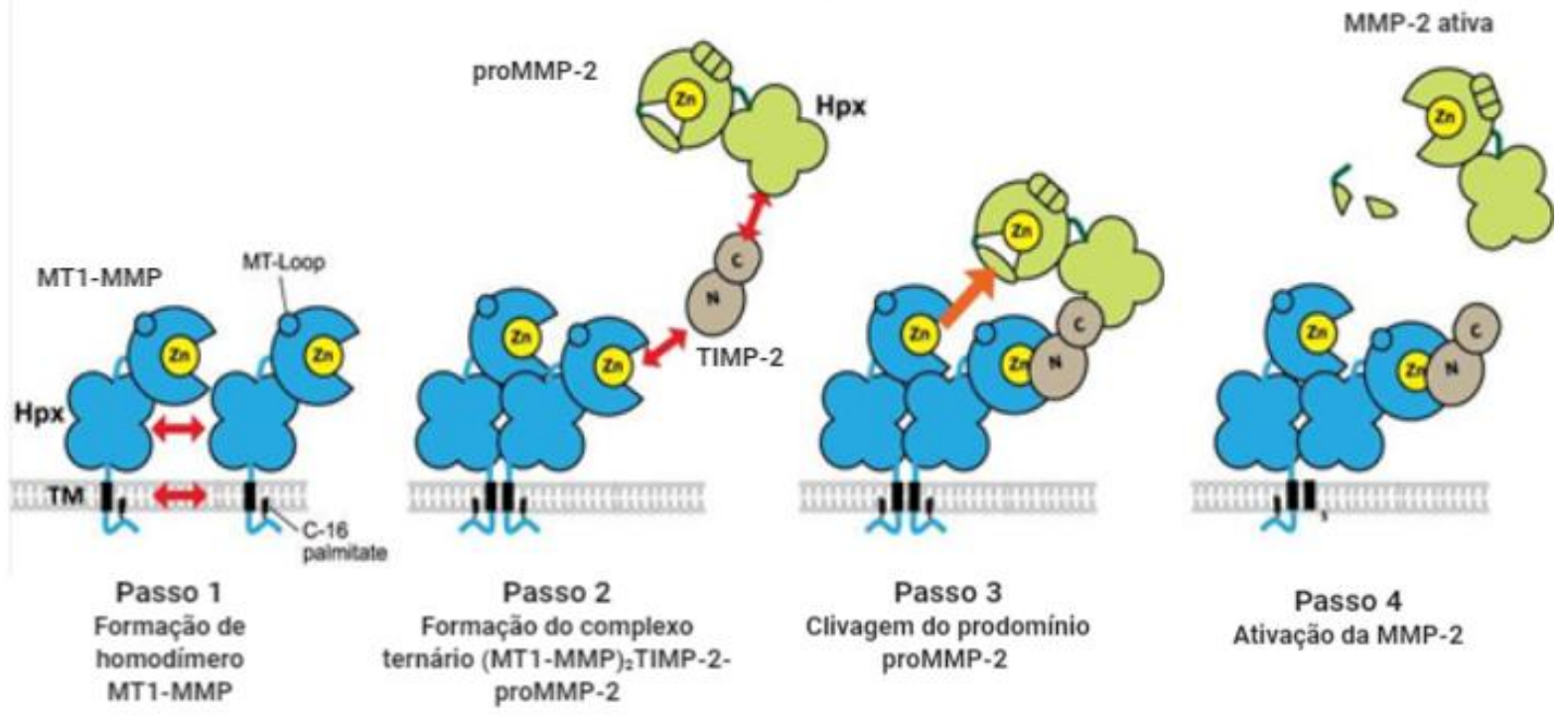

Figura 2: Ativação do pro-MMP-2 pela MT1-MMP na superfície celular (Fonte: Gifford; Itoh, 2019). 
Devido à natureza dupla do TIMP-2 na regulação da ativação de MMP-2, em que tanto uma diminuição quanto um excesso da expressão de TIMP-2 podem impedir a ativação de MMP-2, pequenas mudanças no equilíbrio entre os níveis de TIMP e MMP podem modular grandemente o fenótipo invasivo de células tumorais (LU et al., 2004). Metaloproteinases transmembrana, por sua vez, são ativadas no meio intracelular e então deslocadas para a superfície da membrana plasmática, com manutenção de um domínio intracelular (GIFFORD; ITOH, 2019).

A MT1-MMP promove a invasão celular, degradando diretamente a MEC pericelular para facilitar a migração (GIFFORD; ITOH, 2019; PAHWA; STAWIKOWSKI; FIELDS, 2014). Os colágenos são as moléculas da MEC mais abundantes e, dentre as cinco colagenases (MMP-1, -2, -8, -13, MT1-MMP), a MT1MMP é a única enzima que promove diretamente a migração celular em um ambiente colagênico. Foi demonstrado que uma grande variedade de células, incluindo fibroblastos, células endoteliais e células cancerígenas, usa o programa de invasão dependente de MT1-MMP na matriz de colágeno (GIFFORD; ITOH, 2019). Expressões de MT1-MMP foram inicialmente reportadas em células de carcinoma pulmonar em adição aos fibroblastos adjacentes (SEIKI, 2003). Assim, a expressão de MT1-MMP e a ativação de MMP-2 foram correlacionadas com o prognóstico em portadores de neoplasias e padrões de expressões gênicas das duas proteases também foram demonstrados como intensamente correlatos (NAKAMURA et al., 1999).

A MMP-2 está implicada na carcinogênese e características invasivas de vários tipos de câncer (ARONER et al., 2015; DONG et al., 2011). Estudos relataram que o carcinoma papilífero superexpressa a MMP-2 e sugerem um papel importante para essa enzima na progressão tumoral (NAKAMURA et al., 1999; ZEDENIUS et al., 1996). Sabe-se que as linhagens celulares de carcinoma da tireoide com um potencial altamente metastático exibem maior atividade da MMP-2 do que as linhagens celulares menos metastáticas (NAKAMURA et al., 1999). Resultados imunoistoquímicos mostraram que a superexpressão da MMP-2 nos tecidos da tireoide está associada à ocorrência de CPT e metástase linfonodal (SHI et al., 2018). 
Os níveis de TIMP-2 geralmente não parecem estar alterados entre tumores e amostras normais adjacentes (ROSENTHAL; MATRISIAN, 2006). No entanto, foi sugerido que TIMPs e MMPs ativos estão associados ao alto potencial maligno em carcinomas papilíferos da tireoide, sendo que o TIMP-2 está superexpresso nas células tumorais e esta alteração foi associada a um tamanho tumoral elevado e alta invasividade (MAETA; OHGI; TERADA, 2001). A colocalização de pro-MMP-2, TIMP-2 e MT1-MMP nas células tumorais e nas células estromais adjacentes ao tumor foi demonstrada nos carcinomas de tireoide por imunoistoquímica (NAKAMURA et al., 1999). Assim, esta combinação pode acelerar a ação proteolítica da MMP-2, gerando um mecanismo poderoso para as células cancerígenas invadirem e metastatizarem através da degradação dos componentes da MEC ao redor das células cancerígenas e componentes da membrana basal ao redor dos vasos sanguíneos (SHIOMI; OKADA, 2003).

Com isso, o presente estudo teve como objetivo identificar e caracterizar a expressão imunoistoquímica da MT1-MMP, MMP-2 e TIMP-2 no microambiente tumoral de pacientes com carcinoma papilífero de tireoide e correlacioná-la com a progressão da doença e os dados clínicos e histopatológicos de importância prognóstica, uma vez que entender os mecanismos moleculares do CPT pode ser útil na identificação de novos alvos terapêuticos. 


\section{OBJETIVO GERAL}

Avaliar o padrão de expressão da MT1-MMP, MMP-2 e TIMP-2 em carcinomas papilíferos de tireoide (CPT) utilizando imunoistoquímica, bem como as possíveis associações entre a expressão desses marcadores e os aspectos clínicos e patológicos dos tumores.

\subsection{Objetivos específicos}

- Correlacionar a casuística com os achados clínicos e histopatológicos para elucidação da progressão tumoral no carcinoma papilífero da tireoide.

- Caracterizar a expressão e a localização imunoistoquimica da MT1-MMP, MMP-2 e TIMP-2 em tumores primários de carcinoma papilífero da tireoide sem metástase.

- Caracterizar a expressão e a localização imunoistoquimica da MT1-MMP, MMP-2 e TIMP-2 em tumores primários de carcinoma papilífero da tireoide e em suas respectivas metástases linfonodais cervicais.

- Avaliar se há associação entre a expressão dos marcadores e a evolução clínica dos pacientes.

- Analisar a matriz colagênica (colágenos tipo I e III) em tumores primários de carcinoma papilífero da tireoide de pacientes com ausência e presença de metástase linfonodal e em tecido tireoidiano saudável. 


\section{MATERIAL E MÉTODOS}

\subsection{Casuística}

Foi feita uma análise de material arquivado de 30 pacientes com carcinoma papilífero da tireoide tratados cirurgicamente no Hospital das Clínicas- FMRP (USP) durante o período de 2010 a 2015. Todos os pacientes submetidos à cirurgia assinaram o Termo de Consentimento Livre e Esclarecido (TCLE) que permite a utilização de todos os dados clínicos e patológicos que constem em seu prontuário, resguardando-se o sigilo sobre a sua identidade. O estudo foi aprovado pelo Comitê de Ética em Pesquisa de Experimentação Humana da Faculdade de Medicina de Ribeirão Preto da Universidade de São Paulo (USP), de acordo com o processo HCRP n 12.322/ 2019 e Parecer Consubstanciado n³.774.499 (Anexo).

As lâminas arquivadas coradas por hematoxilina-eosina (HE) foram reavaliadas pelo patologista responsável para certificar o diagnóstico e selecionar as biópsias com a área de lesão mais representativa. Nesta fase, foram selecionados blocos em que os tecidos não apresentavam autólise, artefatos ou sinais de processamento inadequados e que apresentaram tumor em pelo menos dez campos de grande aumento (400x). Biópsias de pacientes com descrição no prontuário médico de sorologia positiva para o HIV ou qualquer condição orgânica relacionada com imunossupressão ou com história prévia de radioterapia para tratamento de neoplasias foram excluídas do estudo.

Dados demográficos, tais como sexo, faixa-etária, cor, estado geral de saúde, classee grupos sociais, não representaram critérios de exclusão ou de inclusão. Posteriormente, nova revisão foi feita pelo patologista responsável e foram escolhidos os blocos correspondentes as lâminas mais representativas de lesão como corte com maiores dimensões, maiores graus de atipías e amostragem representativa de parênquima tireoidiano ao redor. Os casos selecionados foram estratificados em 3 grupos: tumor primário de CPT com metástase (CPTM), metástase linfonodal cervical (ML) e tumor primário de CPT sem metástase (CPTS). 
Nos casos de CPTM foi analisado o tumor primário e suas respectivas áreas de metástase linfonodal (ML). Dos 30 casos analisados, 25 pertenciam ao grupo CPTM e 5 do grupo CPTS. Também foram incluídas no estudo, 5 tireoides saudáveis obtidas através de autópsias realizadas no Hospital das Clínicas de Ribeirão Preto/ USP.

As informações clinico-patológicas tais como idade, sexo, tamanho do tumor, presença de metástase e óbito foram coletados dos prontuários do Hospital das Clínicas da FMRP. Os carcinomas foram estadiados de acordo com o tamanho do tumor, metástases linfonodais e metástases distantes, de acordo com os critérios definidos pelo sistema de classificação TNM da American Joint Committee on Cancer ( $7^{\circ}$ edição). Os pacientes com recidiva foram aqueles com recorrência local, quando são detectados restos tireoidianos ou recidivas no leito tireoidiano ou gânglios cervicais. A partir disso, foram realizadas secções dos blocos escolhidos para a realização das reações de imunoistoquímica.

\subsection{Reações de imunoistoquímica}

Cortes de $5 \mu \mathrm{m}$ de espessura foram obtidos em criostato Leica CM 1850 (Leica Instruments, Nusslich, Alemanha) e transferidos para lâminas de vidro silanizadas. As lâminas com os cortes foram deixadas na estufa $110^{\circ} \mathrm{C}$ durante uma hora parafixação das secções nas lâminas. Em seguida, foram retiradas e mantidas àtemperatura ambiente por uma hora até o momento da reação. Os anticorpos primários utilizados na marcação das proteínas foram MT1-MMP, MMP-2 e TIMP-2 pelo sistema de detecção livre de biotina, utilizando o kit Reveal Spring ${ }^{\circledR}$, Biogen, Pleasanton, CA, USA.

Os cortes foram desparafinizados em xilol, reidratados em uma bateria de álcool com concentração decrescente e lavados em água. A reação foi desenvolvida utilizando recuperação antigênica em panela de pressão durante 35 minutos a $95^{\circ} \mathrm{C}$, com tampão citrato $10 \mathrm{mM}$ e pH 6,0. O bloqueio das peroxidases endógenas foi realizado com solução de peróxido de hidrogênio por 15 minutos. As ligações 
inespecíficas foram bloqueadas com solução contendo caseína para bloqueio de proteínas Ultra $\mathrm{V}$ (kit Reveal Spring ${ }^{\circledR}$, Biogen, Pleasanton, CA, USA) durante 10 minutos. Na sequência, as lâminas foram incubadas com os anticorpos primários com a diluição citada na Tabela 2, overnight em câmara úmida e temperatura ambiente. Após a lavagem das lâminas em PBS, foi aplicado o reagente facilitador de conjugado (complemento) (kit Reveal Spring $\AA^{\circledR}$, Biogen, Pleasanton, CA, USA), durante 10 minutos. Em seguida, foi aplicado o conjugado HRP por 15 minutos e como revelador a solução de diaminobenzidina-peroxidase (DAB), acrescentada em tempo padrão para cada um dos cortes. Os cortes foram contracorados com Hematoxilina de Harris por 40 segundos e lavadas em água com hidróxido de amônia. Após reidratação dos cortes em soluções de álcool absoluto e xilol, as lâminas foram montadas com lamínulas interfaceadas com resina sintética. Para as reações dos marcadores, foram utilizadas amostras de placentas humanas como controle positivo.

Tabela 2: Descrição dos anticorpos utilizados na reação de imunoistoquímica.

\begin{tabular}{|c|c|c|c|}
\hline MARCADORES & TIPO & MARCA & DILUIÇÃO \\
\hline MT1-MMP & $\begin{array}{l}\text { Monoclonal } \\
\text { camundongo }\end{array}$ & Santa Cruz & $1: 300$ \\
\hline MMP-2 & $\begin{array}{l}\text { Monoclonal } \\
\text { camundongo }\end{array}$ & Abcam & $1: 100$ \\
\hline TIMP-2 & $\begin{array}{l}\text { Monoclonal } \\
\text { camundongo }\end{array}$ & Millipore & $1: 300$ \\
\hline
\end{tabular}

\subsection{Análise dos marcadores MT1-MMP, MMP-2, TIMP-2}

As lâminas foram analisadas em microscópio de luz convencional, sendo consideradas positivas células aquelas coradas de marrom após a reação. Todos os casos foram analisados pelo patologista sem o conhecimento dos dados clínicos e histopatológicos. Foi verificada a presença ou ausência de marcação, além da 
intensidade da marcação sendo atribuídos os escores 0 para ausência de marcação, escore 1 para marcação fraca, escore 2 para marcação moderada e escore 3 para marcação intensa. Avaliou-se também a localização desta marcação nas células (núcleo, citoplasma ou transmembranar) e a distribuição no tecido.

\subsection{Microscopia óptica}

Cortes de $5 \mu \mathrm{m}$ de espessura foram obtidos em criostato Leica CM 1850 (Leicalnstruments, Nusslich, Alemanha) para avaliação de colágeno tecidual (tipos I e III), utilizando a coloração Picrosirius Vermelho. As lâminas foram desparafinizadas e hidratadas em série decrescente de álcoois e lavadas emágua corrente. A seguir, foram colocadas em solução fosfomolibdico a $2 \%$ por 2 minutos e lavadas em água corrente. Com isso, foram deixadas em solução vermelho da Síria a $0,1 \%$ por 90 minutos e lavadas em água corrente. As lâminas foram passadas pelo $\mathrm{HCl} 0,01 \mathrm{~N}$ por 2 minutos e lavadas em água corrente. Por último, as lâminas foram desidratadas e montadas com resina sintética. A análise morfométrica foi realizada utilizando microscópio óptico sob luz polarizada da marca LEICA (Leica DMR, Leica Microsystems Wetzlar $\mathrm{GmbH}$, Wetzlar, Alemanha), acoplada a uma videocâmara (Leica DC300F, Leica Microsystems AG, Heebrugg, Suíça) e análise pelo software Image-Pro Plus 6.0 (Media Cybernetics, Inc.).

A análise de colágeno foi feita em amostras de tireoide normal e comparadas com os grupos CPTM e CPTS ( $n=5 /$ grupo). Este método permite a diferenciação do colágeno tipo I (birrefringência laranja-amarelado a laranja e vermelha) e tipo III (birrefringência verde ou verde-amarela). De cada lâmina foram selecionados e fotomicrografados 5 campos histológicos no aumento de 40x. Os campos foram selecionados da esquerda para a direita e de cima para baixo. 


\subsection{Análise estatística}

Todas as análises foram realizadas com o auxílio do software SAS Statistical Software (version 9.4; SAS Institute, Inc. Cary, NC, 2013) e para todas as comparações adotou-se um nível de significância de $5 \%$. Para verificar a associação entre as características clínico-patológicas e marcadores, foi utilizado o modelo de regressão logística multinomial ordinal. Este modelo permite associar variáveis independentes com uma variável resposta, sendo esta do tipo categórica ordinal com mais de dois níveis. Para verificar a associação entre os grupos (CPTS, CPTM e ML) e marcadores, foi utilizado o modelo de regressão logística multinomial ordinal com medidas repetidas. Este modelo permite associar variáveis independentes com uma variável resposta, sendo esta do tipo categórica ordinal com mais de dois níveis e repetição de medidas de um mesmo indivíduo (HEDEKER; GIBBONS, 1994). As comparações entre os grupos em relação ao colágeno foram realizadas através da análise de variância (ANOVA). Também foi utilizado o pós-teste de Tukey para as comparações múltiplas. Esse método têm como pressuposto que seus resíduos tem distribuição normal com média 0 e variância $\sigma^{2}$ constante. 


\section{RESULTADOS}

\subsection{Análise descritiva dos aspectos clínicos}

De acordo com a análise descritiva dos dados clínicos dos 30 casos, pode-se observar que a maioria dos casos era do sexo feminino (73,3\%). Assim, foi observada uma relação de proporção de 3 mulheres para cada homem $(3: 1)$. No grupo CPTM, 76 \% pertenciam ao sexo feminino. Já no grupo CPTS, $60 \%$ eram do sexo feminino. A média de idade no diagnóstico foi de 37,5 \pm 15 anos, estando o paciente mais novo com 13 anos e o mais velho com 79 anos.

No estudo foi utilizado o sistema de estadiamento TNM do American Joint Committee on Cancer (AJCC), com base na sétima edição, em que é usado para prever a sobrevida e fornecer orientação para o tratamento adequado em pacientes com carcinoma diferenciado da tireoide. Esta classificação também discrimina pacientes com doença em estadio inicial daqueles com doença avançada de acordo com quatro estádios (LAMARTINA et al., 2018; ZHI et al., 2020). No presente estudo, os pacientes abaixo de 45 anos foram classificados no estadio I e os que possuíam idade acima de 45 anos foram classificados no estadio III ou IV. Todos os casos do grupo CPTM sofreram metástases linfonodais cervicais, sendo que nestes pacientes 32\% tiveram recorrência durante o período médio de acompanhamento de $4,1 \pm 1,8$ anos após a tireoidectomia. Também foi observado nesse grupo que $68 \%$ dos pacientes foram classificados nos estadios I ou II e $54,2 \%$ tiveram o tamanho tumoral acima de $2,0 \mathrm{~cm}$. A variante histopatológica predominante no grupo CPTM foi a clássica $(52 \%)$. Um paciente pertencente a este grupo foi a óbito de causa indeterminada, por isso, não foi considerado este fator nas análises clínicopatológicas.

No grupo CPTS, a maioria dos pacientes (80\%) foram classificados nos estadios I ou II e todos tiveram ausência de recorrência até o presente momento. Além disso, $60 \%$ dos pacientes apresentaram o tamanho tumoral abaixo ou igual a 2,0 $\mathrm{cm}$ e a variante histopatológica predominante neste grupo foi a folicular $(60 \%)$. Os dados completos das características clínico-patológicas em cada grupo que será utilizado nas análises a seguir se encontram na Tabela 3. 
Tabela 3: Características clínico-patológicas dos casos do estudo.

\begin{tabular}{|c|c|c|c|}
\hline \multirow[b]{2}{*}{ Características } & \multicolumn{2}{|c|}{ Grupo } & \multirow[b]{2}{*}{ Total } \\
\hline & $\begin{array}{l}\text { CPTM } \\
(n=25)\end{array}$ & $\begin{array}{r}\text { CPTS } \\
(n=5)\end{array}$ & \\
\hline \multicolumn{4}{|l|}{ SEXO } \\
\hline Feminino & $19(76 \%)$ & $3(60 \%)$ & $22(73,3 \%)$ \\
\hline Masculino & $6(24 \%)$ & $2(40 \%)$ & $8(26,7 \%)$ \\
\hline \multicolumn{4}{|l|}{ IDADE } \\
\hline$\leq 45$ anos & $18(72 \%)$ & $4(80 \%)$ & $22(73,3 \%)$ \\
\hline$>45$ anos & $7(28 \%)$ & $1(20 \%)$ & $8(26,6 \%)$ \\
\hline \multicolumn{4}{|l|}{ ESTADIO } \\
\hline | ou || & $17(68 \%)$ & $4(80 \%)$ & $21(70 \%)$ \\
\hline III ou IV & $8(32 \%)$ & $1(20 \%)$ & $9(30 \%)$ \\
\hline \multicolumn{4}{|c|}{ TAMANHO TUMORAL * } \\
\hline$\leq 2 \mathrm{~cm}$ & $11(45,8 \%)$ & $3(60 \%)$ & $14(48,3 \%)$ \\
\hline$>2 \mathrm{~cm}$ & $13(54,2 \%)$ & $2(40 \%)$ & $15(51,7 \%)$ \\
\hline \multicolumn{4}{|l|}{ RECIDIVA } \\
\hline Não & $17(68 \%)$ & $5(100 \%)$ & $22(73,3 \%)$ \\
\hline Sim & $8(32 \%)$ & $0(0 \%)$ & $8(26,7 \%)$ \\
\hline \multicolumn{4}{|c|}{ TIPO HISTOLÓGICO } \\
\hline Clássico & $13(52 \%)$ & $1(20 \%)$ & $14(30 \%)$ \\
\hline Folicular & $7(28 \%)$ & $3(60 \%)$ & $10(33,3 \%)$ \\
\hline Outros ** & $5(20 \%)$ & $1(20 \%)$ & $6(20 \%)$ \\
\hline
\end{tabular}




\subsection{Associação da expressão imunoistoquímica de MT1-MMP, MMP-2 e TIMP-2 com parâmetros clínico-patológicos.}

MT1-MMP

Como observado na tabela 4 , os parâmetros estádio e idade se correlacionaram estatisticamente com a expressão de MT1-MMP. A marcação leve foi maior nos casos com estadiamento I ou II (75\%), porém nos estadios III e IV houve um aumento de marcação moderada $(37,5 \%)(p=0,02)$. Também foi possível observar uma predominância de expressão leve do marcador em pacientes do sexo feminino (70\%), sendo que no sexo masculino $50 \%$ tiveram uma marcação leve e $37,5 \%$ não expressaram a MT1-MMP. Pacientes com idade menor ou igual a 45 anos também tiveram predominância de marcação leve $(76,2 \%)$ e somente $4,8 \%$ tiveram a marcação intensa, porém os que possuem idade superior a 45 anos expressaram a marcação moderada em $42,8 \%$ dos casos $(p=0,01)$. A maior parte dos pacientes apresentou marcação leve no parâmetro tamanho tumoral, tanto acima quanto abaixo de $2 \mathrm{~cm}$. Pacientes com reincidência também tiveram marcação leve em $87,5 \%$ dos casos. Somente os casos de carcinoma papilífero da tireoide variante clássica tiveram marcação moderada e intensa do marcador $(30,8 \%)$. No tipo histológico folicular, houve predominância de marcação leve $(77,8 \%$ dos casos). 
Tabela 4: Comparação entre a expressão de MT1-MMP e os parâmetros clínico-patológicos do CPT.

\begin{tabular}{|c|c|c|c|c|c|}
\hline \multirow{2}{*}{ Características } & \multicolumn{4}{|c|}{ MT1-MMP $(n=28)$} & \multirow{2}{*}{ Valor $\mathbf{p}^{\star}$} \\
\hline & 0 & 1 & 2 & 3 & \\
\hline SEXO & & & & & 0,66 \\
\hline FEMININO & $3(15 \%)$ & $14(70 \%)$ & $2(10 \%)$ & $1(5 \%)$ & \\
\hline MASCULINO & $3(37,5 \%)$ & $4(50 \%)$ & $1(12,5 \%)$ & $0(0 \%)$ & \\
\hline IDADE & & & & & 0,01 \\
\hline$\leq 45$ anos & $4(19 \%)$ & $16(76,2 \%)$ & $0(0 \%)$ & $1(4,8 \%)$ & \\
\hline$>45$ anos & $2(28,6 \%)$ & $2(28,6 \%)$ & $3(42,8 \%)$ & $0(0 \%)$ & \\
\hline ESTADIO & & & & & 0,02 \\
\hline | ou II & $4(20 \%)$ & $15(75 \%)$ & $0(0 \%)$ & $1(5 \%)$ & \\
\hline III ou IV & $2(25 \%)$ & $3(37,5 \%)$ & $3(37,5 \%)$ & $0(0 \%)$ & \\
\hline $\begin{array}{l}\text { TAMANHO } \\
\text { TUMORAL }\end{array}$ & & & & & 0,83 \\
\hline$\leq 2 \mathrm{~cm}$ & $3(25 \%)$ & $9(75 \%)$ & $2(16,6 \%)$ & $0(0 \%)$ & \\
\hline$>2 \mathrm{~cm}$ & $3(23,1 \%)$ & $8(61,5 \%)$ & $1(7,7 \%)$ & $1(7,7 \%)$ & \\
\hline RECIDIVA & & & & & 0,39 \\
\hline NÃO & $5(25 \%)$ & $11(55 \%)$ & $3(15 \%)$ & $1(5 \%)$ & \\
\hline SIM & $1(12,5 \%)$ & $7(87,5 \%)$ & $0(0 \%)$ & $0(0 \%)$ & \\
\hline $\begin{array}{l}\text { TIPO } \\
\text { HISTOLÓGICO }\end{array}$ & & & & & 0,30 \\
\hline CLÁSSICA & $2(15,4 \%)$ & $7(53,8 \%)$ & $3(23,1 \%)$ & $1(7,7 \%)$ & \\
\hline FOLICULAR & $2(22,2 \%)$ & $7(77,8 \%)$ & $0(0 \%)$ & $0(0 \%)$ & \\
\hline OUTROS & $2(33,3 \%)$ & $4(66,7 \%)$ & $0(0 \%)$ & $0(0 \%)$ & \\
\hline
\end{tabular}

* Referente ao modelo de regressão multinomial ordinal; escore 0: marcação nula, escore 1: marcação leve, escore 2: marcação moderada, escore 3: marcação intensa. 
De acordo com a tabela 5, a expressão imunoistoquímica da MMP-2 não mostrou correlação com os parâmetros clínico-patológicos analisados. Porém, observa-se que no sexo masculino, 50\% apresentaram marcação nula, diferente do sexo feminino que teve em $36,4 \%$ dos casos marcação moderada e intensa. Com relação à idade, $41 \%$ dos pacientes com idade menor ou igual a 45 anos apresentaram marcação nula, sendo que $37,5 \%$ dos pacientes com idade acima de 45 anos tiveram marcação intensa. 33,3\% dos pacientes nos estadios I ou II tiveram marcação leve e $44,4 \%$ dos pacientes nos estadios III ou IV apresentaram marcação moderada e intensa. $50 \%$ dos casos com tamanho tumoral abaixo ou igual a $2 \mathrm{~cm}$, tiveram marcação nula e $40 \%$ dos casos com tamanho tumoral acima de $2 \mathrm{~cm}$, tiveram marcação leve. Pacientes com recidiva, 50\% obteve marcação nula e 37,5\% marcação leve. O tipo histológico com marcação moderada mais frequente foi o folicular (44,4\% dos casos). No entanto, a variante clássica apresentou, em 21,4\% dos casos, marcação intensa. 
Tabela 5: Comparação entre a expressão de MMP-2 e os parâmetros clínico-patológicos do CPT.

\begin{tabular}{|c|c|c|c|c|c|}
\hline \multirow{2}{*}{ Características } & \multicolumn{4}{|c|}{ MMP-2 $(n=30)$} & \multirow{2}{*}{ Valor $\mathbf{p}^{\star}$} \\
\hline & 0 & 1 & 2 & 3 & \\
\hline SEXO & & & & & 0,31 \\
\hline FEMININO & $7(31,8 \%)$ & $7(31,8 \%)$ & $4(18,2 \%)$ & $4(18,2 \%)$ & \\
\hline MASCULINO & $4(50 \%)$ & $2(25 \%)$ & $2(25 \%)$ & $0(0 \%)$ & \\
\hline IDADE & & & & & 0,17 \\
\hline$\leq 45$ anos & $9(41 \%)$ & $7(31,8 \%)$ & $5(22,7 \%)$ & $1(4,5 \%)$ & \\
\hline$>45$ anos & $2(25 \%)$ & $2(25 \%)$ & $1(12,5 \%)$ & $3(37,5 \%)$ & \\
\hline ESTADIO & & & & & 0,23 \\
\hline | ou || & $8(38,1 \%)$ & $7(33,3 \%)$ & $5(23,8 \%)$ & $1(4,8 \%)$ & \\
\hline III ou IV & $3(33,3 \%)$ & $2(22,2 \%)$ & $1(11,1 \%)$ & $3(33,3 \%)$ & \\
\hline $\begin{array}{l}\text { TAMANHO } \\
\text { TUMORAL }\end{array}$ & & & & & 0,15 \\
\hline$\leq 2 \mathrm{~cm}$ & $7(50 \%)$ & $3(21,4 \%)$ & $3(21,4 \%)$ & $1(7,1 \%)$ & \\
\hline$>2 \mathrm{~cm}$ & $3(20 \%)$ & $6(40 \%)$ & $3(20 \%)$ & $3(20 \%)$ & \\
\hline RECIDIVA & & & & & 0,18 \\
\hline NÃO & $7(31,8 \%)$ & $6(27,3 \%)$ & $5(22,7 \%)$ & $4(18,2 \%)$ & \\
\hline SIM & $4(50 \%)$ & $3(37,5 \%)$ & $1(12,5 \%)$ & $0(0 \%)$ & \\
\hline $\begin{array}{l}\text { TIPO } \\
\text { HISTOLÓGICO }\end{array}$ & & & & & 0,28 \\
\hline CLÁSSICA & $6(42,9 \%)$ & $4(28,6 \%)$ & $1(7,1 \%)$ & $3(21,4 \%)$ & \\
\hline FOLICULAR & $3(33,3 \%)$ & $2(22,2 \%)$ & $4(44,4 \%)$ & $0(0 \%)$ & \\
\hline OUTROS & $2(28,6 \%)$ & $3(42,8 \%)$ & $1(14,3 \%)$ & $1(14,3 \%)$ & \\
\hline
\end{tabular}

* Referente ao modelo de regressão multinomial ordinal; escore 0: marcação nula, escore 1: marcação leve, escore 2: marcação moderada, escore 3: marcação intensa. 
$\mathrm{Na}$ comparação entre a expressão imunoistoquímica do TIMP-2 e os parâmetros clínico-patológicos, foi observado que nos pacientes do sexo feminino, a marcação moderada $(45,5 \%)$ foi mais frequente, sendo que no sexo masculino a marcação intensa $(62,5 \%)$ prevaleceu. Pacientes com idade menor ou igual a 45 anos tiveram predominância de marcação moderada $(45,4 \%)$ e os que possuem idade superior a 45 anos expressaram a marcação de forma intensa em $50 \%$ dos casos. A marcação intensa também foi maior nos casos com estadio III ou IV $(55,6 \%)$. Nos pacientes com recidiva, $50 \%$ apresentaram marcação moderada, já os pacientes sem recorrência tiveram expressão intensa em $45,5 \%$ dos casos. $O$ tipo histológico folicular teve predominância de marcação moderada em $66,7 \%$ dos casos. No entanto, a expressão imunoistoquímica do TIMP-2 não mostrou correlação com os parâmetros clínico-patológicos analisados, conforme descrito na tabela 6. 
Tabela 6: Comparação entre a expressão de TIMP-2 e os parâmetros clínico-patológicos do CPT.

\begin{tabular}{|c|c|c|c|c|c|}
\hline \multirow{2}{*}{ Características } & \multicolumn{4}{|c|}{ TIMP-2 $(n=30)$} & \multirow{2}{*}{ Valor $\mathbf{p}$} \\
\hline & 0 & 1 & 2 & 3 & \\
\hline SEXO & & & & & 0,09 \\
\hline FEMININO & - & $5(22,7 \%)$ & $10(45,5 \%)$ & $7(31,8 \%)$ & \\
\hline MASCULINO & - & $0(0 \%)$ & $3(37,5 \%)$ & $5(62,5 \%)$ & \\
\hline IDADE & & & & & 0,79 \\
\hline$\leq 45$ anos & - & $4(18,2 \%)$ & $10(45,4 \%)$ & $8(36,4 \%)$ & \\
\hline$>45$ anos & - & $1(12,5 \%)$ & $3(37,5 \%)$ & $4(50 \%)$ & \\
\hline ESTADIO & & & & & 0,52 \\
\hline | ou II & - & $4(19 \%)$ & $10(47,6 \%)$ & 7 (33,3\%) & \\
\hline III ou IV & - & $1(11,1 \%)$ & $3(33,3 \%)$ & $5(55,6 \%)$ & \\
\hline TAMANHO TUMORAL & & & & & 0,61 \\
\hline$\leq 2 \mathrm{~cm}$ & - & $2(14,3 \%)$ & $7(50 \%)$ & $5(35,7 \%)$ & \\
\hline$>2 \mathrm{~cm}$ & - & $2(13,3 \%)$ & $6(40 \%)$ & $7(46,7 \%)$ & \\
\hline RECIDIVA & & & & & 0,28 \\
\hline NÃO & - & $3(13,6 \%)$ & $9(40,9 \%)$ & $10(45,5 \%)$ & \\
\hline SIM & - & $2(25 \%)$ & $4(50 \%)$ & $2(25 \%)$ & \\
\hline TIPO HISTOLÓGICO & & & & & 0,25 \\
\hline CLÁSSICA & - & $3(21,4 \%)$ & $5(35,7 \%)$ & $6(42,9 \%)$ & \\
\hline FOLICULAR & - & $0(0 \%)$ & $6(66,7 \%)$ & $3(33,3 \%)$ & \\
\hline OUTROS & - & $2(28,6 \%)$ & $2(28,6 \%)$ & $3(42,8 \%)$ & \\
\hline
\end{tabular}

* Referente ao modelo de regressão multinomial ordinal; escore 0: marcação nula, escore 1: marcação leve, escore 2: marcação moderada, escore 3: marcação intensa. 


\subsection{Análise imunoistoquímica dos marcadoresMT1-MMP, MMP-2 e TIMP-2}

A expressão imunoistoquímica dos marcadores MT1-MMP, MMP-2 e TIMP-2 foi analisada em amostras de tireoide normal, em tumores primários de carcinoma papilífero da tireoide sem metástase, em tumores primários de carcinoma papilífero da tireoide com metástase e suas respectivas áreas de metástase (linfonodos).

\section{MT1-MMP}

A protease MT1-MMP mostrou-se frequentemente positiva em todos os grupos e foi identificada no citoplasma das células foliculares. Em alguns casos, possuiu distribuição focal no tecido, sendo que a maior parte apresentou marcação leve, conforme demonstra a tabela 7. Todas as amostras de tireoide normal tiveram expressão nula da MT1-MMP, como observado na figura 3. Não houve diferença entre os grupos CPTS, CPTM e ML $(p=0,33)$. Portanto, o grupo CPTM apresentou marcação leve em 65,2\% dos casos, sendo que na área de metástase linfonodal houve marcação moderada e intensa em $34,7 \%$ dos casos analisados. A marcação leve também foi predominante no grupo CPTS (60\%).

Tabela 7: Distribuição da expressão imunoistoquimica da MT1-MMP nos diferentes grupos.

\begin{tabular}{ccccc}
\hline Marcadores & $\begin{array}{c}\text { CPTM } \\
(\mathbf{n = 2 3 )}\end{array}$ & $\begin{array}{c}\text { ML } \\
(\mathbf{n = 2 3})\end{array}$ & $\begin{array}{c}\text { CPTS } \\
(\mathbf{n = 5})\end{array}$ & Valor $^{*}$ \\
\hline MT1-MMP & $4(17,4 \%)$ & $5(21,7 \%)$ & $2(40 \%)$ & 0,33 \\
0 & $15(65,2 \%)$ & $10(43,5 \%)$ & $3(60 \%)$ & \\
1 & $3(13 \%)$ & $5(21,7 \%)$ & $0(0 \%)$ & \\
2 & $1(4,3 \%)$ & $3(13 \%)$ & $0(0 \%)$ & \\
3 & &
\end{tabular}

*Referente ao modelo de regressão multinomial ordinal com medidas repetidas; escore 0: marcação nula, escore 1: marcação leve, escore 2: marcação moderada, escore 3: marcação intensa. 

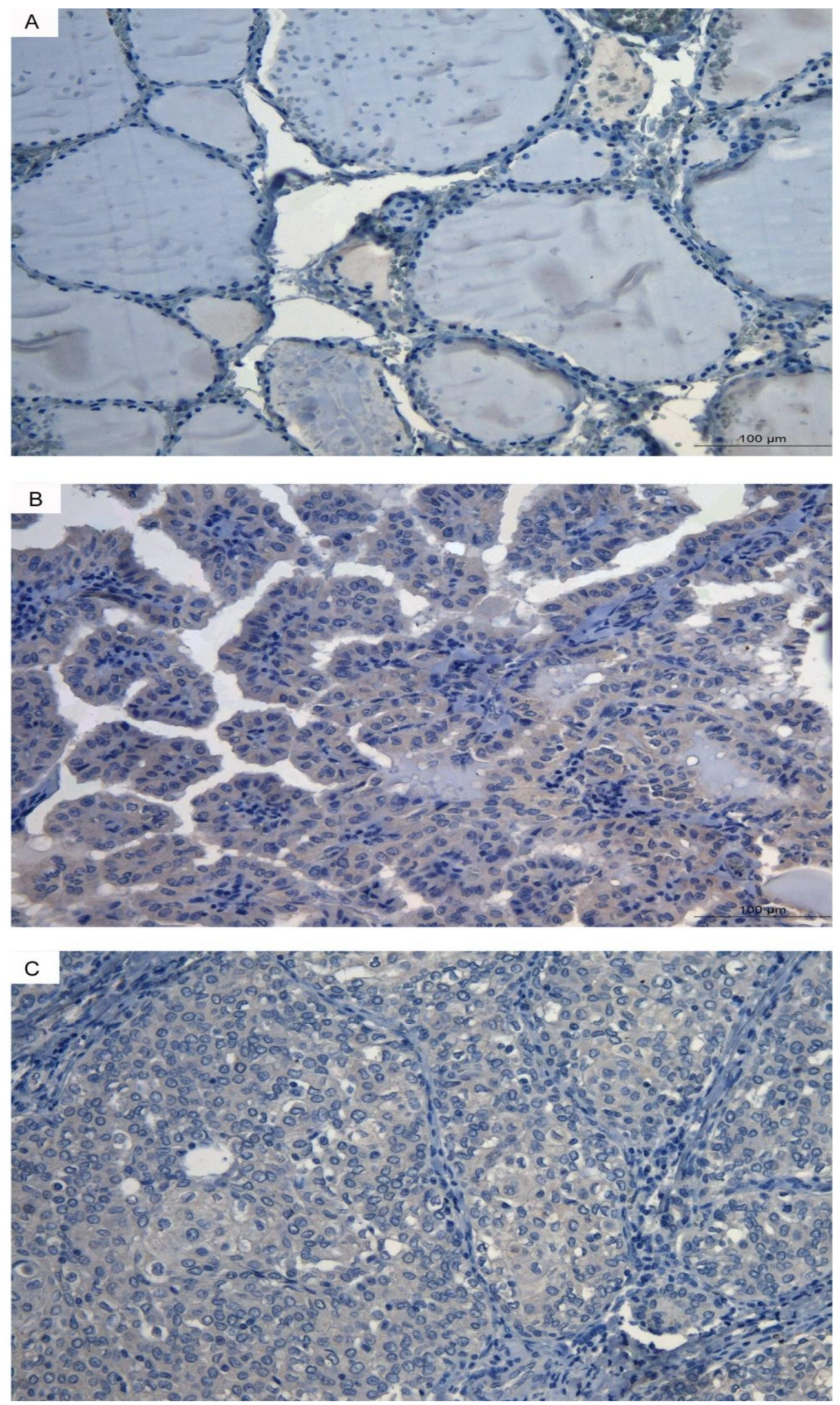

Figura 3: Fotomicrografias da expressão imunoinstoquímica da MT1-MMP (100 $\mu \mathrm{m})$. A. Expressão negativa da MT1-MMP em tecido tireoidiano saudável, B. Marcação citoplasmática positiva de intensidade leve da MT1-MMP em células foliculares da tireoide no grupo CPTS, C. Marcação citoplasmática positiva de intensidade leveda MT1-MMP em células foliculares da tireoide no grupo CPTM. 

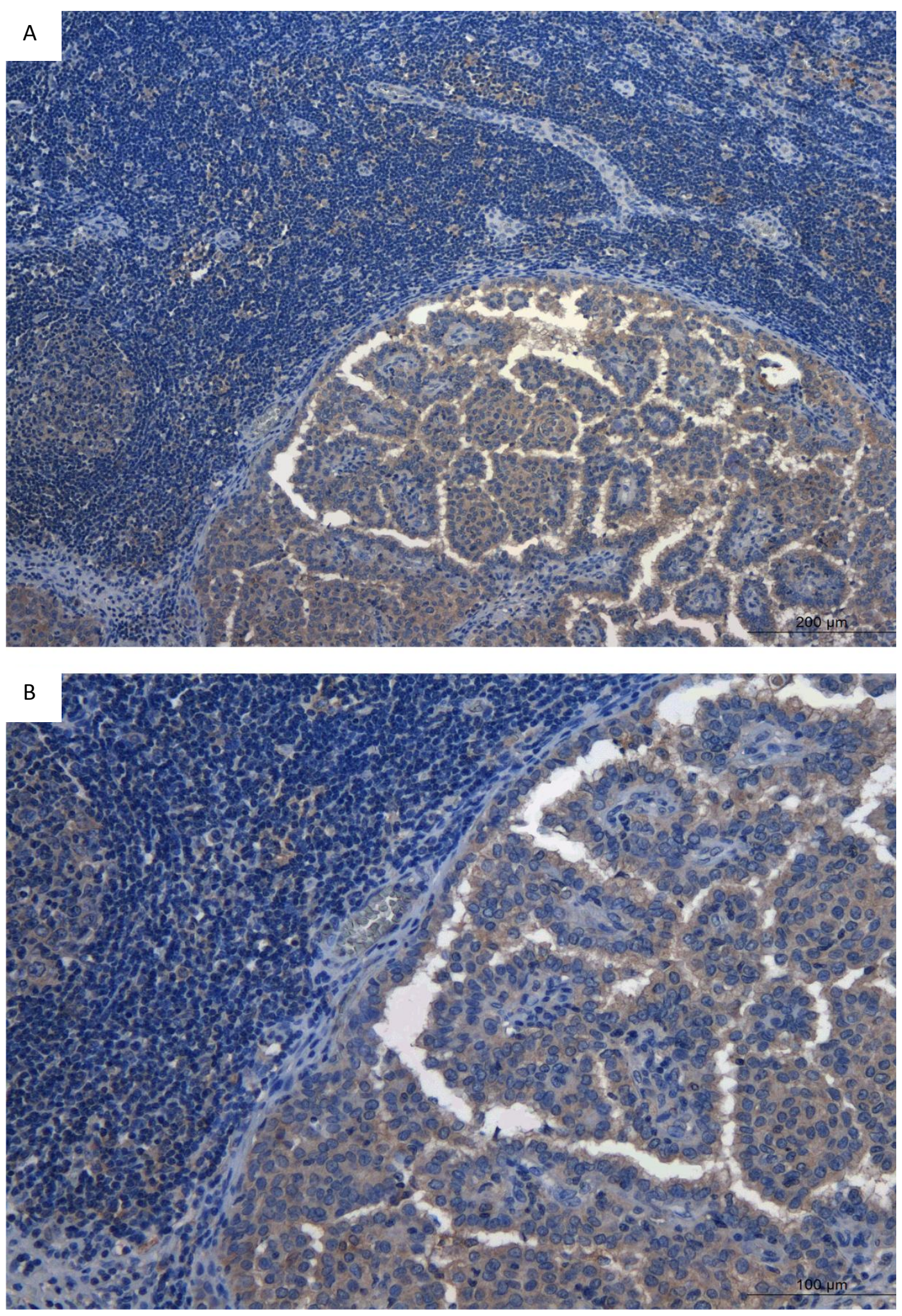

Figura 4: Fotomicrografias da expressão imunoinstoquímica da MT1-MMP de intensidade moderada no citoplasma de células metastáticas no linfonodo (A: $200 \mu \mathrm{m}, \mathrm{B}: 100 \mu \mathrm{m})$. 
A protease MMP-2 apresentou-se predominantemente positiva em todos os grupos e foi identificada no citoplasma das células foliculares. Mostrou possuir distribuição focal no tecido na maior parte dos casos. Todas as amostras de tireoide normal tiveram expressão nula da MMP-2, como observado na figura 5. Não houve diferença entre os grupos CPTS, CPTM e ML $(p=0,53)$. O grupo CPTM apresentou marcação nula em $40 \%$ dos casos e marcação moderada e intensa em $32 \%$ dos casos, diferente da área de metástase linfonodal que houve marcação moderada e intensa em $48 \%$ dos casos analisados. No grupo CPTS, houve marcação leve e moderada na mesma proporção $(40 \%)$ e foi não observada marcação intensa, conforme demonstra a tabela 8.

Tabela 8: Distribuição da expressão imunoistoquimica da MMP-2 nos diferentes grupos.

\begin{tabular}{ccccc}
\hline Marcadores & $\begin{array}{c}\text { CPTM } \\
(\mathbf{n}=25)\end{array}$ & $\begin{array}{c}\text { ML } \\
(\mathbf{n}=25)\end{array}$ & $\begin{array}{c}\text { CPTS } \\
(\mathbf{n}=5)\end{array}$ & Valor $^{*}$ \\
\hline MMP-2 & & & & 0,53 \\
0 & $10(40 \%)$ & $7(28 \%)$ & $1(20 \%)$ & \\
1 & $7(28 \%)$ & $6(24 \%)$ & $2(40 \%)$ & \\
2 & $4(16 \%)$ & $8(32 \%)$ & $2(40 \%)$ & \\
3 & $4(16 \%)$ & $4(16 \%)$ & $0(0 \%)$ & \\
\hline
\end{tabular}

* Referente ao modelo de regressão multinomial ordinal com medidas repetidas; escore 0: marcação nula, escore 1: marcação leve, escore 2: marcação moderada, escore 3: marcação intensa. 

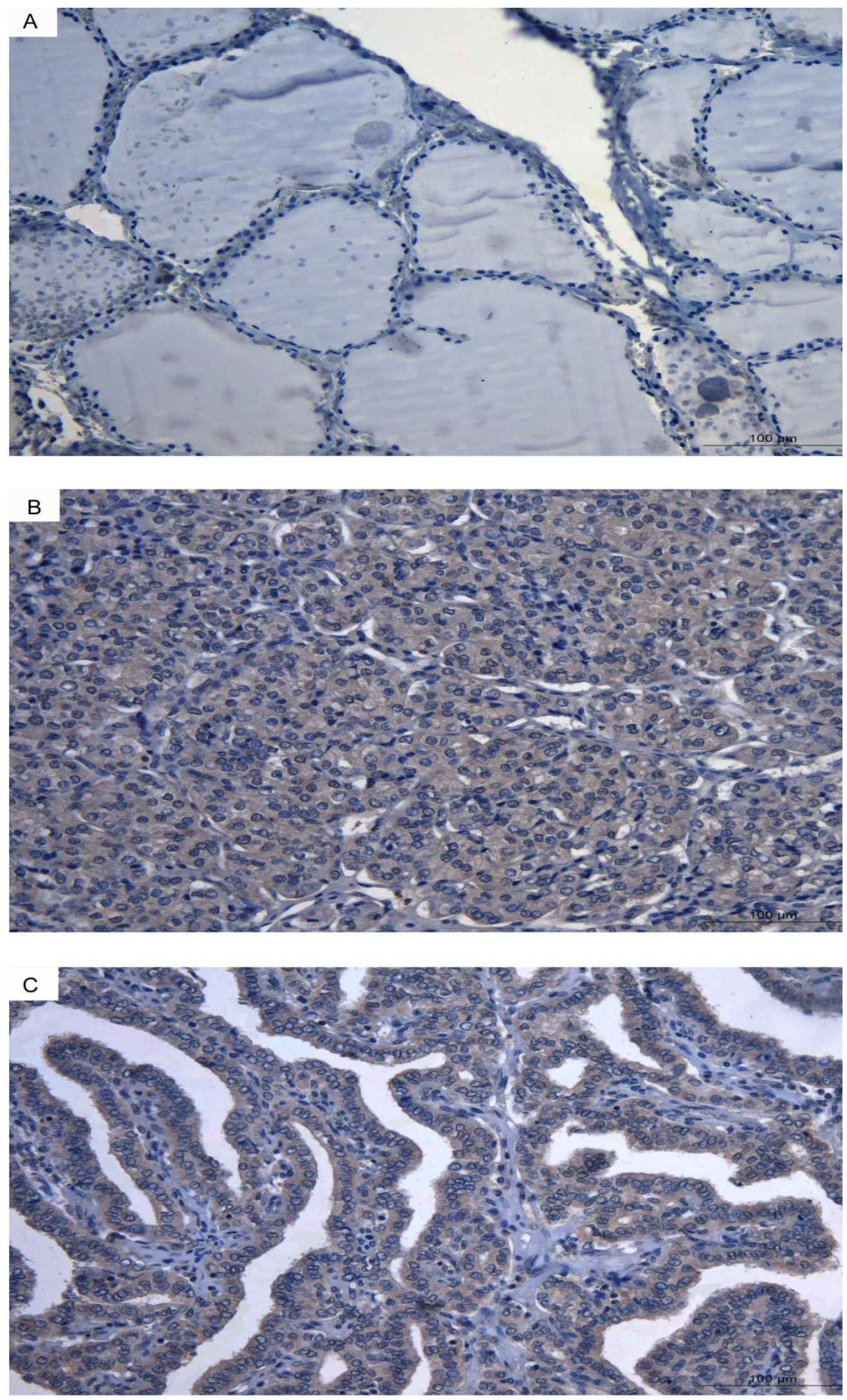

Figura 5: Fotomicrografias da expressão imunoinstoquímica da MMP-2 (100 $\mu \mathrm{m})$. A. Expressão negativa da MMP-2 em tecido tireoidiano saudável, B. Marcação citoplasmática positiva de intensidade moderada da MMP-2 em células foliculares da tireoide no grupo CPTS, C. Marcação citoplasmática positiva de intensidade moderada da MMP-2 em células foliculares da tireoide no grupo CPTM. 

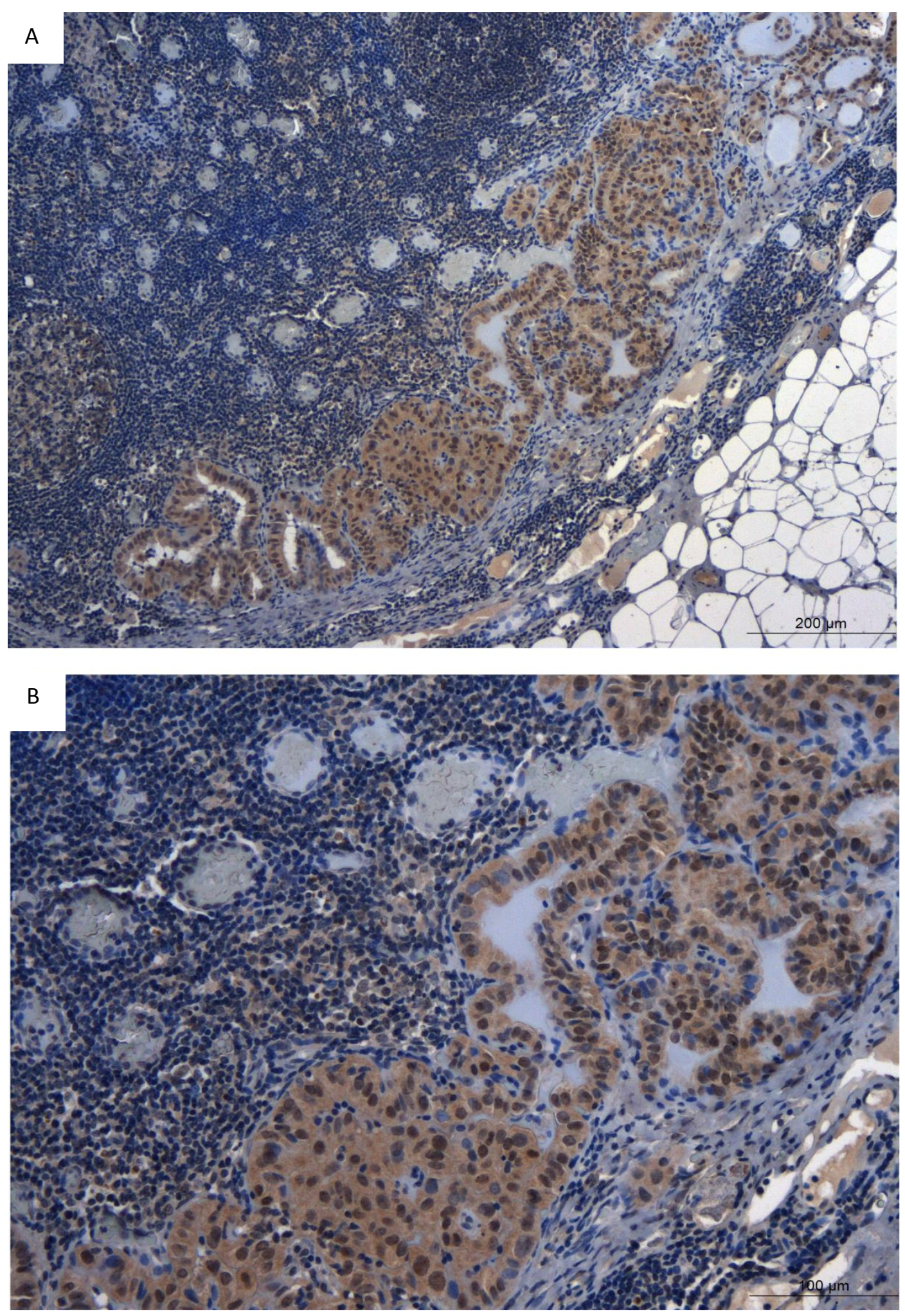

Figura 6: Fotomicrografias da expressão imunoinstoquímica da MMP-2 com intensidade moderada no citoplasma de células metastáticas no linfonodo (A: $200 \mu \mathrm{m}, \mathrm{B}: 100 \mu \mathrm{m})$. 
Não houve marcação nula para o TIMP-2 nos grupos analisados, exceto as amostras de tireoide normal que não expressaram a marcação, como observado na figura 7. O marcador foi identificado no citoplasma das células foliculares, tendo uma distribuição difusa no tecido. Não houve diferença entre os grupos CPTS, CPTM e ML $(p=0,71)$. O grupo CPTM apresentou marcação intensa em 44\% dos casos. $O$ mesmo ocorreu na área de metástase linfonodal, em que a marcação intensa foi observada em 44\% dos casos analisados, porém com predominância da marcação moderada (52\%). No grupo CPTS, houve marcação moderada em $80 \%$ dos casos, conforme demonstra a tabela 9.

Tabela 9: Distribuição da expressão imunoistoquimica do TIMP-2 nos diferentes grupos.

\begin{tabular}{ccccc}
\hline Marcadores & $\begin{array}{c}\text { CPTM } \\
(\mathbf{n}=25)\end{array}$ & $\begin{array}{c}\text { ML } \\
(\mathbf{n}=25)\end{array}$ & $\begin{array}{c}\text { CPTS } \\
(\mathbf{n}=5)\end{array}$ & Valor $^{*}$ \\
\hline TIMP-2 & & & - & 0,71 \\
0 & - & - & $0(0 \%)$ & \\
1 & $5(20 \%)$ & $1(4 \%)$ & $4(80 \%)$ & \\
2 & $9(36 \%)$ & $13(52 \%)$ & $1(20 \%)$ & \\
3 & $11(44 \%)$ & $11(44 \%)$ & & \\
\hline
\end{tabular}

*Referente ao modelo de regressão multinomial ordinal com medidas repetidas; escore 0: marcação nula, escore 1: marcação leve, escore 2: marcação moderada, escore 3: marcação intensa. 

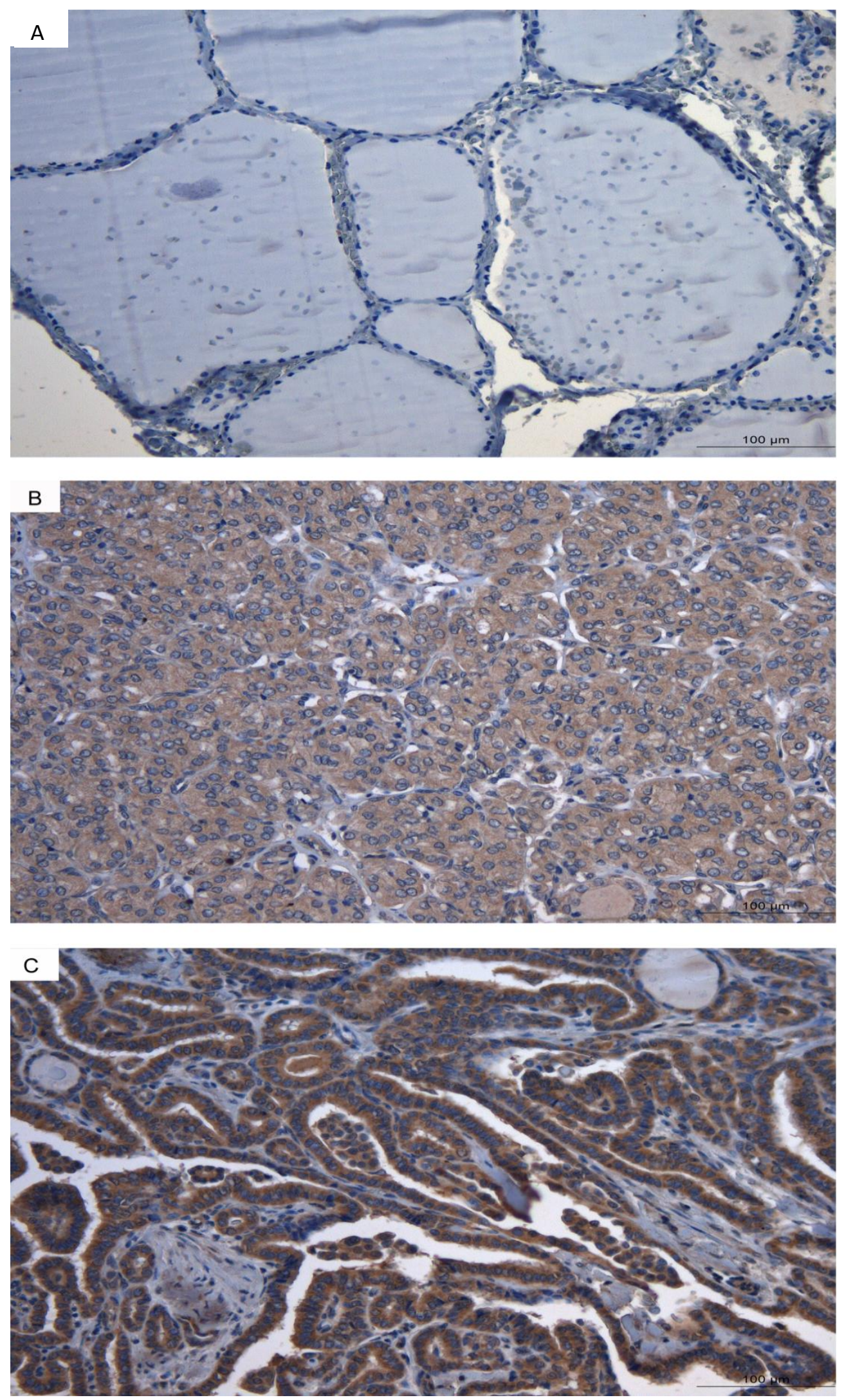

Figura 7: Fotomicrografias da expressão imunoinstoquímica do TIMP-2 (100 $\mu \mathrm{m})$. A. Expressão negativa do TIMP-2 em tecido tireoidiano saudável, B. Marcação citoplasmática positiva com intensidade moderada do TIMP-2 em células foliculares da tireoide no grupo CPTS, C. Marcação citoplasmática positiva intensa do TIMP-2 em células foliculares da tireoide no grupo CPTM. 

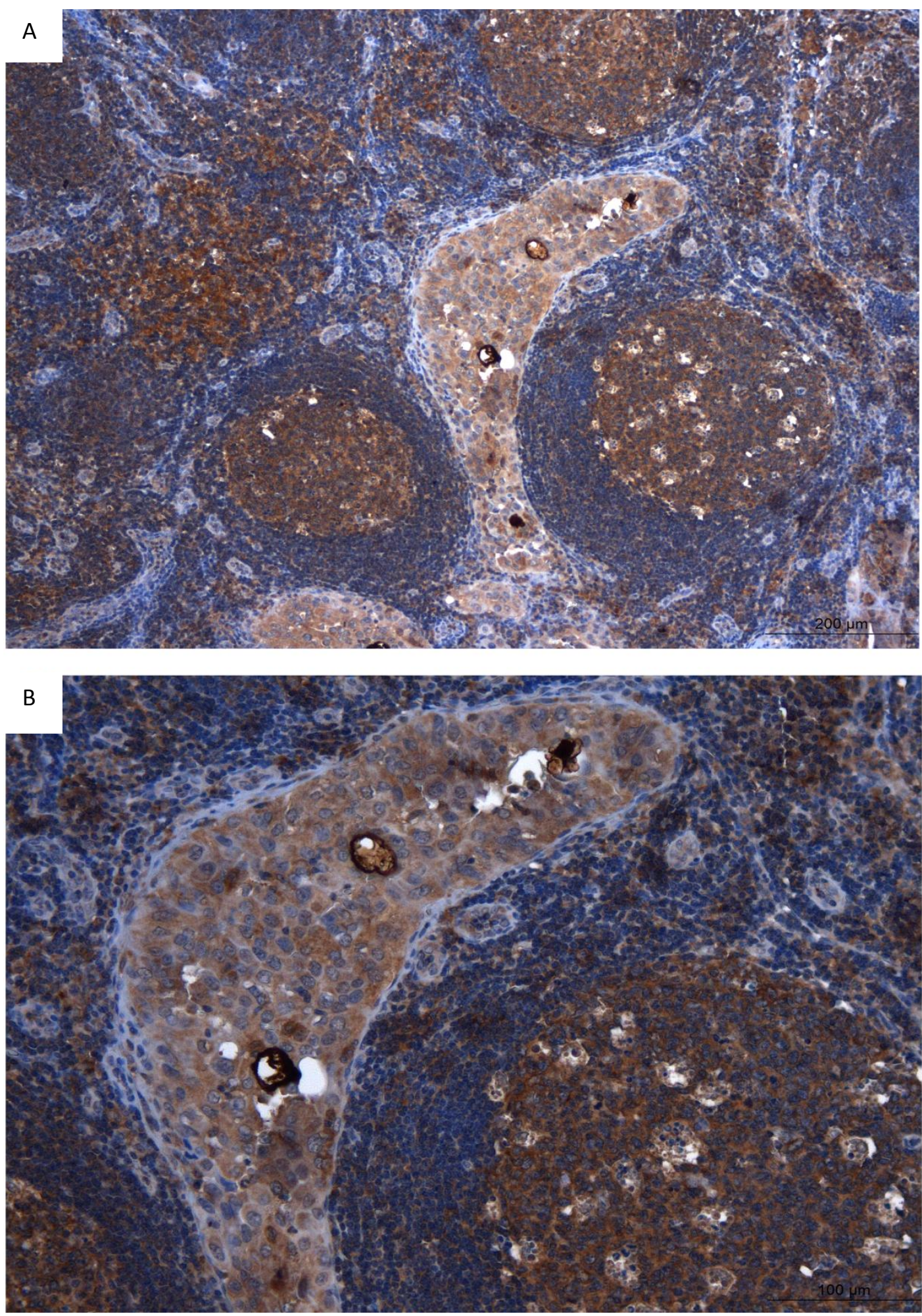

Figura 8: Fotomicrografias da expressão imunoinstoquímica com intensidade moderada do TIMP-2 no citoplasma de células metastáticas no linfonodo (A: $200 \mu \mathrm{m}, \mathrm{B}: 100 \mu \mathrm{m})$. 


\subsection{Análise da expressão concomitante dos marcadores.}

Devido à importância da expressão dos três marcadores para a ativação da via proteolítica estudada, foi feita uma análise da expressão concomitante da MT1MMP, MMP-2 e TIMP-2 nos diferentes grupos. Com isso, pode-se notar que não houve expressão negativa para os três marcadores (MT1-MMP/ MMP-2/ TIMP-2) no mesmo paciente. No grupo CPTM, $48 \%$ dos pacientes expressaram os três marcadores concomitantemente, o restante apresentou expressão positiva para um ou dois marcadores. No local de metástase no linfonodo, um discreto aumento na expressão das três proteínas foi observado (52\%). No grupo CPTS, os resultados foram parecidos, pois $40 \%$ dos pacientes expressaram os três marcadores concomitantemente. Em MT1-MMP/ TIMP-2 observamos que $82,6 \%$ dos pacientescom metástase apresentaram marcação positiva para o marcador, sendo que na área de metástase dos mesmos pacientes, os números foram parecidos (78,3\%). Em MMP-2/ TIMP-2, também foi possível notar que 60\% do grupo CPTM tiveram marcação positiva, e na região de metástase linfonodal houve um aumento do número em $72 \%$. No grupo CPTS, esse expressão concomitante foi vista em $80 \%$ dos pacientes. Porém, não observamos diferença entre os grupos, conforme mostra a tabela 10 . 
Tabela 10: Análise da correlação entre a expressão concomitante dos marcadores e a progressão tumoral do carcinoma papilífero da tireoide.

\begin{tabular}{|c|c|c|c|c|}
\hline Marcadores & СРTM & ML & CPTS & Valor $\mathbf{p}^{*}$ \\
\hline MT1-MMP/ MMP-2 & & & & 0,80 \\
\hline $\begin{array}{l}\text { Ambos com expressão } \\
\text { negativa }\end{array}$ & $2(8,7 \%)$ & $1(4,4 \%)$ & $0(0 \%)$ & \\
\hline $\begin{array}{l}\text { Um dos marcadores com } \\
\text { expressão positiva }\end{array}$ & $9(39,1 \%)$ & $9(39,1 \%)$ & $3(60 \%)$ & \\
\hline $\begin{array}{l}\text { Ambos com expressão } \\
\text { positiva }\end{array}$ & $12(52,2 \%)$ & $13(56,5 \%)$ & $2(40 \%)$ & \\
\hline MT1-MMP/ TIMP-2 & & & & 0,58 \\
\hline $\begin{array}{l}\text { Ambos com expressão } \\
\text { positiva }\end{array}$ & $19(82,6 \%)$ & $18(78,3 \%)$ & $3(60 \%)$ & \\
\hline $\begin{array}{l}\text { Um dos marcadores com } \\
\text { expressão positiva }\end{array}$ & $4(17,4 \%)$ & $5(21,7 \%)$ & $2(40 \%)$ & \\
\hline MMP-2/ TIMP-2 & & & & 0,56 \\
\hline $\begin{array}{l}\text { Ambos com expressão } \\
\text { positiva }\end{array}$ & $15(60 \%)$ & $18(72 \%)$ & $4(80 \%)$ & \\
\hline $\begin{array}{l}\text { Um dos marcadores com } \\
\text { expressão positiva }\end{array}$ & $10(40 \%)$ & $7(28 \%)$ & $1(20 \%)$ & \\
\hline MT1-MMP/ MMP-2/ TIMP-2 & & & & 0,89 \\
\hline Todos com expressão positiva & $12(48 \%)$ & $13(52 \%)$ & $2(40 \%)$ & \\
\hline $\begin{array}{l}\text { Um ou dois marcadores com } \\
\text { expressão positiva }\end{array}$ & $13(52 \%)$ & $12(48 \%)$ & $3(60 \%)$ & \\
\hline
\end{tabular}

*referente ao modelo de regressão multinomial ordinal com medidas repetidas. 


\subsection{Análise da matriz colagênica.}

A expressão do colágeno tipo I e III foi analisada em amostras de tireoide normal, em tumores primários de carcinoma papilífero da tireoide sem metástase e em tumores primários de carcinoma papilífero da tireoide com metástase, para analisar alterações na matriz colagênica. Houve uma alteração considerável de colágeno tipo I entre os grupos tireoide saudável e CPTM $(p<0,001)$ e entre os grupos tireoide saudável e CPTS $(p<0,001)$. Não houve diferença entre os grupos CPTM e CPTS. Apesar da diminuição considerável do colágeno tipo III no CPT, não houve diferença estatística entre os diferentes grupos, conforme observado na tabela 11 e 12 .

Tabela 11: Comparação da expressão de colágeno tipo I nos diferentes grupos.

\begin{tabular}{cccccc}
\hline Variáveis & Comparações & $\begin{array}{c}\text { Estimativa } \\
\text { média* da } \\
\text { diferença }\end{array}$ & IC 95\% & Valor $\mathbf{p}$ \\
\hline COLAGENO & Tireoide Saudável - CPTM & 4,18 & 1,33 & 9,26 & $<0,01$ \\
TIPO I & Tireoide Saudável - CPTS & 3,96 & 0,97 & 9,12 & $<0,01$ \\
& CPTM - CPTS & $-0,22$ & $-1,12$ & 0,78 & 0,7995 \\
\hline
\end{tabular}


Tabela 12: Análise da matriz colagênica (colágeno tipo I e III) nos diferentes grupos.

\begin{tabular}{|c|c|c|c|c|c|c|c|c|c|c|}
\hline Variáveis & Grupo & Média & $\begin{array}{l}\text { Desvio } \\
\text { Padrão }\end{array}$ & Mediana & $\begin{array}{c}10 \\
\text { Quartil }\end{array}$ & $\begin{array}{c}\text { 3o } \\
\text { Quartil }\end{array}$ & Mínimo & Máximo & Valor $p^{*}$ & $\begin{array}{c}\text { Pós-teste } \\
\text { de } \\
\text { Tukey** }\end{array}$ \\
\hline \multirow{3}{*}{ COLAGENO TIPO I } & Tireoide Saudável & 6,274 & 3,905 & 5,44 & 4,657 & 9,799 & 1,012 & 10,465 & & $A$ \\
\hline & СРTM & 0,722 & 0,364 & 0,639 & 0,481 & 0,867 & 0,35 & 1,275 & $<0,01^{a}$ & B \\
\hline & CPTS & 1,02 & 0,685 & 0,854 & 0,633 & 1,011 & 0,423 & 2,178 & & B \\
\hline \multirow{3}{*}{ COLÁGENO TIPO III } & Tireoide Saudável & 1,765 & 0,981 & 2,01 & 0,839 & 2,02 & 0,801 & 3,157 & & \\
\hline & СРTM & 0,991 & 0,711 & 0,739 & 0,547 & 1,654 & 0,194 & 1,82 & 0,10 & - \\
\hline & CPTS & 0,737 & 0,298 & 0,695 & 0,604 & 0,888 & 0,355 & 1,145 & & \\
\hline
\end{tabular}

*ANOVA

${ }^{a}$ transformação logarítmica 

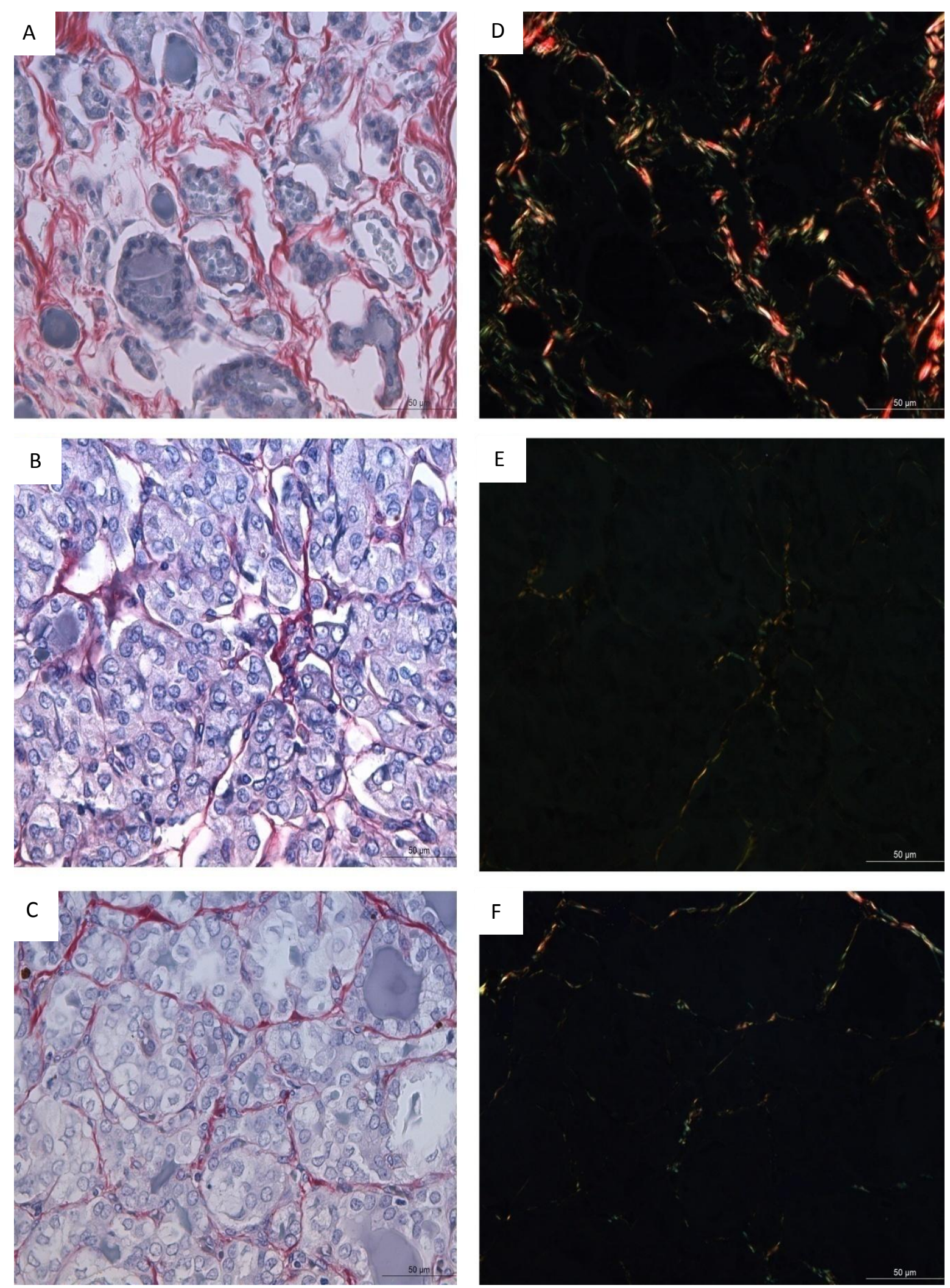

Figura 9: Fotomicrografias das fibras colágenas, evidenciando, em vermelho, o colágeno tipo I e, em verde, o colágeno tipo III $(50 \mu \mathrm{m})$. A e D: Tecido tireoidiano saudável, B e E: Grupo CPTS, C e F: Grupo CPTM. No painel do lado esquerdo (A, B, C), observam-se cortes histológicos corados com Picrosirius Red e do lado direito (D, E, F), os mesmos cortes, porém sob microscopia de luz polarizada. 


\section{DISCUSSÃO}

O carcinoma papilífero da tireoide é a forma mais comum de malignidade da tireoide, sendo responsável por $60-70 \%$ de todos os cânceres de tireoide e ocorre com mais frequência em mulheres entre a quarta e quinta décadas de vida. Sua incidência mais que dobrou nas últimas três décadas. A taxa de mortalidade, no entanto, manteve-se estável com um bom prognóstico, com uma taxa de sobrevivência relacionada à doença em 10 anos acima de 90\% (MANSOUR et al., 2018). Investigações mostraram que vários fatores clínicos demonstraram ter valor prognóstico no CPT, como idade avançada, tamanho tumoral, presença de metástases linfonodais e distantes ou extensão extratireoidiana (VUONG et al., 2017). A classificação UICC TNM, que é o sistema de classificação mais amplamente adotado, estabeleceu uma idade de corte de 45 anos. Nosso estudo demonstra que os pacientes que evoluíram para a metástase linfonodal, 76\% pertenciam ao sexo feminino ea idade média foi de 37 anos. Devido à idade ser menor que 45 anos e não existir nos grupos presença de metástase à distância, $68 \%$ dos casos no grupo CPTM foram classificados no estadio I.

Foi demonstrado correlação entre o tamanho do tumor acima de $2 \mathrm{~cm}$ e o risco de metástases linfonodais, extensão extratireoidiana e metástases à distância (TRAN et al., 2018). No entanto, não observamos essa correlação no presente estudo, pois $54,2 \%$ dos pacientes com metástase linfonodal possuíam o tamanho do tumor primário acima de $2 \mathrm{~cm}$. Também foi observado no grupo CPTM que $32 \%$ tiveram reincidência durante o período médio de acompanhamento de $4,1 \pm 1,8$ anos após a tireoidectomia. Outro estudo mostrou um período médio de recorrência após tireoidectomia primária com dissecção de linfonodos de 3,4 \pm 1,7 anos (LIU et al., 2015). A variante histológica mais frequente nos pacientes com metástase foi a clássica (52\%), seguida pelo padrão folicular (28\%). Clinicamente, acredita-se que a variante folicular do CPT se comporta de forma semelhante ao CPT clássico. Porém, estudos observaram uma menor prevalência de metástases linfonodais na variante folicular, o que corrobora com nossos resultados, que mostram que $60 \%$ dos pacientes com ausência de metástase apresentaram o padrão folicular. Além disso, calcificação, corpos psamomatosos e formação óssea foram detectados com menos 
frequência na variante folicular de CPT em comparação com o tipo clássico (LAM; LO; LAM, 2005).

Embora o câncer seja uma doença multifatorial, já foi demonstrado que o crescimento e a proliferação de células cancerígenas são amplamente influenciados por sua interação mecânica com o microambiente (HUANG et al., 2019). As metaloproteinases de matriz (MMPs) são um grupo de endopeptidases dependentes de zinco que digerem a matriz intercelular, afetando assim o microambiente tumoral, promovendo angiogênese, crescimento tumoral e metástase (KESSENBROCK; PLAKS; WERB, 2010). Como as MMPs estão localizadas na superfície da célula, elas também estão envolvidas nas vias de sinalização de outras funções celulares, como proliferação, apoptose e diferenciação. Qualquer perturbação desses mecanismos reguladores em condições patológicas pode levar à deterioração da doença. Portanto, a transcrição de MMPs é estritamente regulada e sua expressão costuma ser muito baixa. A regulação da atividade de MMP ocorre por meio da tradução de enzimas que precisam ser ativadas, bem como a coexpressão de inibidores de tecido de metaloproteinases (ZHANG et al., 2018). O papel das MMPs na progressão tumoral foi demonstrado no carcinoma de pulmão, mama, cólon e próstata. Entretanto, no carcinoma de tireoide, a importância das MMPs na promoção da metástase têm sido controversa (PATEL et al., 2002). Com isso, neste estudo, caracterizou-se a expressão imunoistoquímica da MT1-MMP, MMP-2 e TIMP-2 e correlacionamos os achados com parâmetros clínico-patológicos e com a progressão tumoral. Estudos que investigaram as expressões de MMPs e TIMPs no CPT focaram principalmente na diferenciação de nódulos tireoidianos malignos de benignos (BALDINI et al., 2004; LIU et al., 2019). O presente estudo focou principalmente no CPT metastático.

Dessa forma, nossos dados mostram um predomínio da expressão leve de MT1MMP nos grupos CPTS e CPTM, esse padrão é mantido na área de metástase linfonodal, porém a marcação moderada e intensa dobrou quando comparada com a lesão primária do grupo CPTM. Contudo, não foi observado diferenças entre os grupos. É sabido que a MT1-MMP é capaz de degradar macromoléculas da MEC, como colágenos tipo I e III, e essa degradação é acelerada pela ação coordenada da MMP-2 ativada pela MT1-MMP (SHIOMI; OKADA, 2003). Alguns outros estudos 
já demonstraram a presença de MT1-MMP no tecido tireoidiano e tem sido amplamente associada a papéis cruciais na progressão de cânceres humanos, comoocarcinoma de células escamosas de cabeça e pescoço, onde foi identificado como uma variável determinante para o desenvolvimento de metástases em linfonodos (CAVALHEIRO; JUNQUEIRA; BRANDÃO, 2010; IMANISHI et al., 2000). No entanto, outro estudo mostra que a MT1-MMP é expressa de forma semelhante em tumores benignos e malignos (carcinomas papilíferos e foliculares) da tireoide em crianças e adolescentes, onde a MT1-MMP foi positivamente expressa em 97\% nos casos de CPT e correlacionada com a recorrência da doença (PATEL et al., 2002). No presente estudo, observamos positividade da marcação em $82,6 \%$ dos casos que evoluíram para a metástase e em $60 \%$ dos casos de CPT sem metástase e essa expressão foi correlacionada com o alto estadio da doença (III-IV) e idade. Apesar disso, a MT1-MMP não foi correlacionada com a formação de metástases linfonodais cervicais no CPT em nosso estudo, o que difere dos achados de Nakamura et al., que relatou que a expressão de MT1-MMP desempenhou um papel fundamental na formação de metástases linfonodais no CPT. Porém, outro trabalho demonstrou que os níveis de produção de MT1-MMP são significativamente maiores em carcinomas de glândulas salivares do que em tecidos de glândulas salivares não neoplásicas. No entanto, nenhuma correlação foi obtida entre os níveis de produção e fatores clínico patológicos, incluindo metástases em linfonodos (KAYANO et al., 2004). Além disso, não observamos marcação positiva para a MT1MMP em tecido tireoidiano saudável e as células com capacidade de metastizar possuem o padrão de expressão da MT1-MMP parecido com as células do tumor primário.

Altos níveis da expressão de MMP-2 estão associados a comportamentos tumorais agressivos em muitos carcinomas. Em neoplasias da tireoide, as MMPs, particularmente a MMP-2, parecem estar associadas ao potencial metastático (BUMBER et al., 2020). Níveis elevados de MMP-2 no CPT mostraram se correlacionar com a presença de metástase (MAETA; OHGI; TERADA, 2001). No presente estudo, verificamos positividade da MMP-2 em 80\% dos casos de CPT sem metástase. Já na lesão primária do CPT com metástase, 60\% apresentaram marcação positiva, sendo que na área de metástase dos mesmos pacientes houve um aumento da marcação moderada e intensa (48\%). No entanto, outro estudo 
mostrou que o nível aumentado de expressão da proteína MMP-2 nos tumores primários e na metástase do CPT está relacionado com a frequência de metástase cervical nesta doença e pode, portanto, estar envolvida na estimulação da via linfática das metástases no CPT. Também foi relatado que a alta expressão imunoistoquímica de MMP-2 está associada a metástases linfonodais, metástases à distância, invasão vascular e intratireoidiana, tamanho tumoral e alto estadio no CPT (MAETA; OHGI; TERADA, 2001). Porém, apesar do aumento da intensidade desse marcador nas células metastáticas nos linfonodos, não observamos diferença estatística entre os grupos. Também não foi observado correlação entre a expressão da MMP-2 e os parâmetros clínico-patológicos. Embora a maioria dos estudos seja a favor do pior prognóstico e do maior potencial metastático em pacientes cujos tumores têm expressão elevada de MMPs, alguns estudos indicam que esse não precisa ser o caso. Foi demonstrado que os escores de expressão de MMP-2 e MT1-MMP não foram diferentes entre os pacientes com ou sem metástases em carcinoma de células escamosas orais (KATAYAMA et al., 2004). Outro trabalho não encontrou diferença significativa entre a expressão da proteína MMP-2 no CPT com e sem metástase (KOREM et al., 2002). Também foi verificado que a expressão de MMP-2 não foi relacionada com parâmetros como sexo ou tamanho do tumor no CPT, o que está em concordância com nossos resultados (SAFFAR et al., 2013). A MMP-2 eseu inibidor,TIMP-2, raramente são produzidos em tecidos normais sem estímulos inflamatórios ou oncogênicos, e assim como nosso estudo, outros autores também não detectaram essas marcações no tecido tireoidiano saudável (MAREČKO et al., 2011).

Em todos os casos foi verificada marcação positiva para o TIMP-2, sendo que no grupo com metástase, tanto o tumor primário quanto a região de metástase linfonodal apresentaram marcação intensa na mesma proporção (44\%), diferente do grupo que não evoluiu para a metástase que possuiu um predomínio de marcação moderada (80\%). Apesar disso, não houve diferença estatística entre os grupos e a expressão também não foi correlacionada com os parâmetros clínicos patológicos. $O$ papel do TIMP-2 ainda é controverso, pois alguns estudos sugerem que em altos níveis podem promover tumorigenicidade, já que a expressão elevada de TIMP-2 foi associada com o mau prognóstico em vários cânceres humanos (CEPEDA et al., 2016). Diferente dos nossos resultados, outros trabalhos correlacionaram as altas 
expressões do TIMP-2 com o tamanho tumoral aumentado e alto estadio clínico (MAETA; OHGl; TERADA, 2001). No entanto, Cavalheiro et al. relataram que embora a imunomarcação de TIMP-2 tenha sido observada em células neoplásicas primárias e metastáticas no carcinoma medular da tireoide, não houve associação com a evolução clínica. Outro estudo também verificou que a expressão de TIMPs não teve uma correlação com a progressão tumoral, pois não apresentou diferença entre a expressão em lesões malignas e benignas da tireoide (NAKAMURA et al., 1999). O TIMP-2 em concentrações mais altas possui a função de inibir a atividade da MMP-2, formando complexos estáveis com o sítio ativo dessa protease. Por outro lado, o TIMP-2 em baixa concentração colabora para a ativação da pro-MMP-2 (KRENGEL et al., 2002). Foi relatado que a alta ativação de MMP-2, detectada por ensaio zimográfico, está associada à alta expressão de TIMP-2 em células tumorais. Portanto, a imunorreatividade de TIMP-2 é provavelmente útil para monitorar a ativação de MMP-2 (YOSHIZAKI et al., 1997). Este fato pode explicar o fato do TIMP-2 estar em altas concentrações em nosso estudo, e por não ter sido correlacionado com um mau prognóstico, é provável que a alta expressão tenha causado um efeito inibidor da MMP-2.

Assim, devido à importância da presença dessas três proteínas no tecido para ativar a via proteolítica, analisamos a correlação da expressão concomitante com a progressão tumoral e observamos que $48 \%$ dos pacientes com CPT que evoluíram para a metástase tiveram positividade para os três marcadores e na região de suas respectivas metástases linfonodais, 52\% expressaram os três marcadores. $40 \%$ dos pacientes com CPT sem metástase apresentaram a expressão concomitante dos marcadores. Com isso, fica evidente que nem todos os pacientes que evoluíram para a metástase possuem expressão concomitante dessas proteínas em células malignas do CPT e as células que conseguiram ultrapassar as barreiras e metastizar para os linfonodos, possuem o mesmo padrão que as células do tumor primário. No entanto,o estudo realizado apresentou limitações importantes quanto ao tamanho amostral.

Além disso, observamos alterações significativas na matriz nos grupos com CPT, houve uma expressiva diminuição de fibras colágenas tipo I nos grupos com e sem metástase quando comparados com o tecido normal. Com a coloração de 
Picrosirius, observamos uma modificação na arquitetura e distribuição das fibras colágenas que foram parecidas nos grupos CPT com e sem metástase. No entanto, outro trabalho relatou uma superexpressão de colágeno tipo I no CPT quando comparada com o tecido normal e também relatou que pacientes com baixa expressão de colágeno tipo I exibiram uma sobrevida livre de doença mais longa do que aqueles com alta expressão no CPT. Uma análise adicional dos fatores de risco de sobrevida livre de doença confirmou que a alta expressão de colágeno tipo I teve valor preditivo para uma sobrevida livre de doença mais curta (HUANG et al., 2019). Porém, no presente estudo, realizamos a análise da matriz que envolve as células foliculares, onde há a presença de uma das maiores proteases colagenolíticas, a MT1-MMP, e houve uma considerável diminuição de colágeno I e III no CPT, apesar do colágeno tipo III não ter sido considerado estatisticamente diferente do tecido normal. Não realizamos, neste estudo, análise da cápsula tireoidiana, o que pode ser o motivo dos nossos resultados serem diferentes dos estudados anteriormente, que utilizam técnicas quantitativas que envolvem todo o tecido.

Com isso, nossos resultados sugerem que houve um remodelamento das propriedades biomecânicas da MEC nos estágios iniciais da tumorigênese. Proteases colagenolíticas são ativadas no microambiente tumoral, como por exemplo a MT1-MMP, e sua expressão/atividade pode ser influenciada por hormônios, fatores de crescimento e citocinas (CUI; HU; KHALIL, 2017). Com isso, pequenas mudanças na homeostase do microambiente podem ter efeitos significativos na proliferação de células cancerosas. Mudanças na deposição ou degradação do colágeno podem levar à perda da homeostase da matriz. À medida que as células tumorais proliferam, a MEC circundante sofre alterações arquitetônicas significativas em uma interação dinâmica entre o microambiente e as células residentes (WALKER; MOJARES; DEL RÍO HERNÁNDEZ, 2018). Sabe-se que a degradação proteolítica é indispensável para as propriedades de penetração nos tecidos das células cancerosas através do colágeno tipo I. Um estudo demonstrou que a colagenólise mediada por MT1-MMP juntamente com a produção de força conduzida pela actina causam o aumento dos poros da matriz para promover a transmigração nuclear e invasão celular no câncer de mama (FERRARI et al., 2019). No entanto, nossos resultados não se correlacionam com a progressão 
tumoral. Estudos adicionais são necessários para demonstrar o papel do colágeno na metástase e invasão nos carcinomas de tireoide. 


\section{CONCLUSÃO}

A expressão imunoistoquimica da MT1-MMP possuiu correlação com fatores clínico-patológicos como alto estadiamento (III-IV) e idade acima de 45 anos, em que houve predomínio de marcação moderada.

O carcinoma papilífero da tireoide apresentou um aumento da expressão de MT1-MMP, MMP-2 e TIMP-2 quando comparadas com o tecido tireoidiano saudável.

As proteases MT1-MMP, MMP-2 e seu inibidor TIMP-2 não foram correlacionados com a formação de metástases linfonodais cervicais, pois houve um padrão de expressão parecido entre os grupos CPTS, CPTM e suas respectivas áreas de metástase linfonodal cervical (ML).

A maior parte dos pacientes que evoluíram para a metástase, não apresentou expressão concomitante do complexo ternário MT1-MMP/ MMP-2/ TIMP-2 e as células que conseguiram desprender da lesão primária e metastizar para os linfonodos, possuíam o mesmo padrão de expressão dos marcadores que as células do tumor primário.

Houve uma diminuição do colágeno tipo I no CPT, juntamente com uma modificação na arquitetura e distribuição das fibras colágenas, sendo característicos do remodelamento nos estágios iniciais da doença. Essa diminuição foi menos relevante para o colágeno tipo III. Mais estudos são necessários para avaliar a participação do colágeno na progressão tumoral. 


\section{REFERÊNCIAS}

ABDULLAH, M. I. et al. Papillary Thyroid Cancer: Genetic Alterations and Molecular Biomarker Investigations. International Journal of Medical Sciences, v. 16, n. 3, p. 450-460, 2019.

ARONER, S. A. et al. Plasma matrix metalloproteinase 2 levels and breast cancer risk. Cancer epidemiology, v. 39, n. 3, p. 321-327, jun. 2015.

ATKINSON, S. J. et al. Intermolecular Autolytic Cleavage Can Contribute to the Activation of Progelatinase A by Cell Membranes. Journal of Biological Chemistry, v. 270, n. 51, p. 30479-30485, 22 dez. 1995.

BALDINI, E. et al. Expression of matrix metalloproteinases and their specific inhibitors in normal and different human thyroid tumor cell lines. Thyroid: Official Journal of the American Thyroid Association, v. 14, n. 11, p. 881-888, nov. 2004.

BARBOSA, M. P. et al. Metastatic lymph node characteristics as predictors of recurrence/persistence in the neck and distant metastases in differentiated thyroid cancer. Archives of Endocrinology and Metabolism, v. 61, n. 6, p. 584-589, dez. 2017.

BONNANS, C.; CHOU, J.; WERB, Z. Remodelling the extracellular matrix in development and disease. Nature Reviews. Molecular Cell Biology, v. 15, n. 12, p. 786-801, dez. 2014.

BREW, K.; NAGASE, H. The tissue inhibitors of metalloproteinases (TIMPs): An ancient family with structural and functional diversity. Biochimica et biophysica acta, v. 1803, n. 1, p. 55-71, jan. 2010.

BUMBER, B. et al. Role of matrix metalloproteinases and their inhibitors in the development of cervical metastases in papillary thyroid cancer. Clinical Otolaryngology, v. 45, n. 1, p. 55-62, 2020.

$\mathrm{CAO}$, J. et al. Membrane Type 1 Matrix Metalloproteinase Induces Epithelial-toMesenchymal Transition in Prostate Cancer. Journal of Biological Chemistry, v. 283, n. 10, p. 6232-6240, 3 jul. 2008.

CASTRO-CASTRO, A. et al. Cellular and Molecular Mechanisms of MT1-MMPDependent Cancer Cell Invasion. Annual Review of Cell and Developmental Biology, v. 32, n. 1, p. 555-576, 6 out. 2016.

CAVALHEIRO, B. G.; JUNQUEIRA, C. R.; BRANDÃO, L. G. Expression of membrane type 1 matrix metalloproteinase in medullary thyroid carcinoma: prognostic implications. Head \& Neck, v. 32, n. 1, p. 58-67, jan. 2010.

CELIÀ-TERRASSA, T.; KANG, Y. Distinctive properties of metastasis-initiating cells. Genes \& Development, v. 30, n. 8, p. 892-908, 15 abr. 2016. 
CEPEDA, M. A. et al. Less is more: low expression of MT1-MMP is optimal to promote migration and tumourigenesis of breast cancer cells. Molecular Cancer, v. 15, 18 out. 2016.

CHA, S. T. et al. Cerebellopontine angle metastasis from papillary carcinoma of the thyroid: case report and literature review. Surgical Neurology, v. 54, n. 4, p. 320326, 1 out. 2000.

CUI, N.; HU, M.; KHALIL, R. A. Biochemical and Biological Attributes of Matrix Metalloproteinases. Progress in molecular biology and translational science, $\mathrm{v}$. 147, p. 1-73, 2017.

DERYUGINA, E. I.; QUIGLEY, J. P. Matrix metalloproteinases and tumor metastasis. Cancer and Metastasis Reviews, v. 25, n. 1, p. 9-34, mar. 2006.

DONG, W. et al. Matrix metalloproteinase 2 promotes cell growth and invasion in colorectal cancer. Acta Biochimica et Biophysica Sinica, v. 43, n. 11, p. 840-848, 1 nov. 2011.

DUFFY, M. J.; MCCARTHY, K. Matrix metalloproteinases in cancer: prognostic markers and targets for therapy (review). International Journal of Oncology, v. 12, n. 6, p. 1343-1348, jun. 1998.

EBLE, J. A.; NILAND, S. The extracellular matrix in tumor progression and metastasis. Clinical \& Experimental Metastasis, v. 36, n. 3, p. 171-198, 2019.

FERRARI, R. et al. MT1-MMP directs force-producing proteolytic contacts that drive tumor cell invasion. Nature Communications, v. 10, 25 out. 2019.

GEURTS, N.; OPDENAKKER, G.; VAN DEN STEEN, P. E. Matrix metalloproteinases as therapeutic targets in protozoan parasitic infections. Pharmacology \& Therapeutics, v. 133, n. 3, p. 257-279, mar. 2012.

GIFFORD, V.; ITOH, Y. MT1-MMP-dependent cell migration: proteolytic and nonproteolytic mechanisms. Biochemical Society Transactions, v. 47, n. 3, p. 811826, 28 jun. 2019.

GUO, K.; WANG, Z. Risk factors influencing the recurrence of papillary thyroid carcinoma: a systematic review and meta-analysis. International Journal of Clinical and Experimental Pathology, v. 7, n. 9, p. 5393-5403, 15 ago. 2014.

HAUGEN, B. R. et al. 2015 American Thyroid Association Management Guidelines for Adult Patients with Thyroid Nodules and Differentiated Thyroid Cancer: The American Thyroid Association Guidelines Task Force on Thyroid Nodules and Differentiated Thyroid Cancer. Thyroid, v. 26, n. 1, p. 1-133, 1 jan. 2016.

HE, L. et al. Matrix Metalloproteinase-14 Is a Negative Prognostic Marker for Patients with Gastric Cancer. Digestive Diseases and Sciences, v. 58, n. 5, p. 1264-1270, 1 maio 2013.

HEDEKER, D.; GIBBONS, R. D. A random-effects ordinal regression model for multilevel analysis. Biometrics, v. 50, n. 4, p. 933-944, dez. 1994. 
HUANG, C. et al. The prognostic potential of alpha-1 type I collagen expression in papillary thyroid cancer. Biochemical and Biophysical Research Communications, v. 515, n. 1, p. 125-132, 122019.

IMANISHI, Y. et al. Clinical significance of expression of membrane type 1 matrix metalloproteinase and matrix metalloproteinase-2 in human head and neck squamous cell carcinoma. Human Pathology, v. 31, n. 8, p. 895-904, 1 ago. 2000.

INCA, MS. Câncer de tireoide. Disponível em: <https://www.inca.gov.br/tipos-decancer/cancer-de-tireoide>. Acesso em: 8 set. 2020.

INSUA-RODRÍGUEZ, J.; OSKARSSON, T. The extracellular matrix in breast cancer. Advanced Drug Delivery Reviews, v. 97, p. 41-55, 1 fev. 2016.

$\mathrm{ITOH}, \mathrm{Y}$. Membrane-type matrix metalloproteinases: Their functions and regulations. Matrix Biology: Journal of the International Society for Matrix Biology, v. 44-46, p. 207-223, jul. 2015.

JABŁOŃSKA-TRYPUĆ, A.; MATEJCZYK, M.; ROSOCHACKI, S. Matrix metalloproteinases (MMPs), the main extracellular matrix (ECM) enzymes in collagen degradation, as a target for anticancer drugs. Journal of Enzyme Inhibition and Medicinal Chemistry, v. 31, n. sup1, p. 177-183, 2016.

JANICKI, J. S. et al. The dynamic interaction between matrix metalloproteinase activity and adverse myocardial remodeling. Heart Failure Reviews, v. 9, n. 1, p. 33-42, jan. 2004.

JIANG, Y.; GOLDBERG, I. D.; SHI, Y. E. Complex roles of tissue inhibitors of metalloproteinases in cancer. Oncogene, v. 21, n. 14, p. 2245-2252, mar. 2002.

JONES, J. L.; GLYNN, P.; WALKER, R. A. Expression of MMP-2 and MMP-9, their inhibitors, and the activator MT1-MMP in primary breast carcinomas. The Journal of Pathology, v. 189, n. 2, p. 161-168, out. 1999.

JOO, Y. E. et al. Expression of tissue inhibitors of metalloproteinases (TIMPs) in gastric cancer. Digestive Diseases and Sciences, v. 45, n. 1, p. 114-121, jan. 2000.

KAI, F.; DRAIN, A. P.; WEAVER, V. M. The Extracellular Matrix Modulates the Metastatic Journey. Developmental Cell, v. 49, n. 3, p. 332-346, 062019.

KALLAKURY, B. V. et al. Increased expression of matrix metalloproteinases 2 and 9 and tissue inhibitors of metalloproteinases 1 and 2 correlate with poor prognostic variables in renal cell carcinoma. Clinical Cancer Research: An Official Journal of the American Association for Cancer Research, v. 7, n. 10, p. 3113-3119, out. 2001.

KATAYAMA, A. et al. Expressions of Matrix Metalloproteinases in Early-Stage Oral Squamous Cell Carcinoma as Predictive Indicators for Tumor Metastases and Prognosis. Clinical Cancer Research, v. 10, n. 2, p. 634-640, 15 jan. 2004. 
KAYANO, K. et al. Activation of pro-MMP-2 mediated by MT1-MMP in human salivary gland carcinomas: possible regulation of pro-MMP-2 activation by TIMP-2. The Journal of Pathology, v. 202, n. 4, p. 403-411, abr. 2004.

KESSENBROCK, K.; PLAKS, V.; WERB, Z. Matrix Metalloproteinases: Regulators of the Tumor Microenvironment. Cell, v. 141, n. 1, p. 52-67, 2 abr. 2010.

KOREM, S. et al. Increased expression of matrix metalloproteinase-2: a diagnostic marker but not prognostic marker of papillary thyroid carcinoma. The Israel Medical Association journal: IMAJ, v. 4, n. 4, p. 247-251, abr. 2002.

KRENGEL, S. et al. MMP-2, TIMP-2 and MT1-MMP are differentially expressed in lesional skin of melanocytic nevi and their expression is modulated by UVB-light. Journal of Cutaneous Pathology, v. 29, n. 7, p. 390-396, 2002.

LA VECCHIA, C. et al. Thyroid cancer mortality and incidence: a global overview. International Journal of Cancer, v. 136, n. 9, p. 2187-2195, 1 maio 2015.

LAM, A. K.-Y.; LO, C.-Y.; LAM, K. S.-L. Papillary carcinoma of thyroid: A 30-yr clinicopathological review of the histological variants. Endocrine Pathology, v. 16, n. 4, p. 323-330, 1 dez. 2005.

LAMARTINA, L. et al. 8th edition of the AJCC/TNM staging system of thyroid cancer: what to expect (ITCO\#2). Endocrine-Related Cancer, v. 25, n. 3, p. L7-L11, 1 mar. 2018.

LEE, M.-H.; MURPHY, G. Matrix metalloproteinases at a glance. Journal of Cell Science, v. 117, n. 18, p. 4015-4016, 15 ago. 2004.

LIU, F. et al. Postoperative recurrence of papillary thyroid carcinoma with lymph node metastasis. Journal of Surgical Oncology, v. 112, n. 2, p. 149-154, 1 ago. 2015.

LIU, J.; KHALIL, R. A. Chapter Ten - Matrix Metalloproteinase Inhibitors as Investigational and Therapeutic Tools in Unrestrained Tissue Remodeling and Pathological Disorders. In: KHALIL, R. A. (Ed.). . Progress in Molecular Biology and Translational Science. Matrix Metalloproteinases and Tissue Remodeling in Health and Disease: Target Tissues and Therapy. [s.I.] Academic Press, 2017. v. 148p. 355-420.

LIU, X. et al. Immunohistochemical analysis of matrix metalloproteinase-9 predicts papillary thyroid carcinoma prognosis. Oncology Letters, v. 17, n. 2, p. 2308-2316, fev. 2019.

LU, H. et al. APE1 Upregulates MMP-14 via Redox-Sensitive ARF6-Mediated Recycling to Promote Cell Invasion of Esophageal Adenocarcinoma. Cancer Research, v. 79, n. 17, p. 4426-4438, 012019.

LU, K. V. et al. Upregulation of tissue inhibitor of metalloproteinases (TIMP)-2 promotes matrix metalloproteinase (MMP)-2 activation and cell invasion in a human glioblastoma cell line. Laboratory Investigation, v. 84, n. 1, p. 8-20, jan. 2004. 
LU, P.; WEAVER, V. M.; WERB, Z. The extracellular matrix: a dynamic niche in cancer progression. The Journal of Cell Biology, v. 196, n. 4, p. 395-406, 20 fev. 2012.

LUO, D. et al. Activation of the ROCK1/MMP-9 pathway is associated with the invasion and poor prognosis in papillary thyroid carcinoma. International Journal of Oncology, v. 51, n. 4, p. 1209-1218, out. 2017.

MACDOUGALL, J. R.; MATRISIAN, L. M. Contributions of tumor and stromal matrix metalloproteinases to tumor progression, invasion and metastasis. Cancer Metastasis Reviews, v. 14, n. 4, p. 351-362, dez. 1995.

MAETA, H.; OHGI, S.; TERADA, T. Protein expression of matrix metalloproteinases 2 and 9 and tissue inhibitors of metalloproteinase 1 and 2 in papillary thyroid carcinomas. Virchows Archiv: An International Journal of Pathology, v. 438, n. 2, p. 121-128, fev. 2001.

MALIK, R.; LELKES, P. I.; CUKIERMAN, E. Biomechanical and biochemical remodeling of stromal extracellular matrix in cancer. Trends in Biotechnology, $v$. 33 , n. 4, p. 230-236, abr. 2015.

MANSO, A. M. et al. Integrins, membrane-type matrix metalloproteinases and ADAMs: Potential implications for cardiac remodeling. Cardiovascular Research, v. 69, n. 3, p. 574-584, 15 fev. 2006.

MANSOUR, J. et al. Prognostic value of lymph node ratio in metastatic papillary thyroid carcinoma. The Journal of Laryngology \& Otology, v. 132, n. 1, p. 8-13, jan. 2018.

MAREČKO, I. et al. Expression of matrix metalloproteinase-2 and its tissue inhibitor-2 in fetal and neoplastic thyroid tissue and their significance as diagnostic and prognostic markers in papillary carcinoma. Cancer Biomarkers: Section A of Disease Markers, v. 11, n. 1, p. 49-58, 20122011.

MCDONNELL, S.; FINGLETON, B. Role of matrix metalloproteinases in invasion, and metastasis: biology, diagnosis and inhibitors. Cytotechnology, v. 12, n. 1, p. 367-384, 1 fev. 1993.

MICHAEL, M. et al. Expression and prognostic significance of metalloproteinases and their tissue inhibitors in patients with small-cell lung cancer. Journal of Clinical Oncology: Official Journal of the American Society of Clinical Oncology, v. 17, n. 6, p. 1802-1808, jun. 1999.

MURUGAN, A. K.; MUNIRAJAN, A. K.; ALZAHRANI, A. S. Long noncoding RNAs: emerging players in thyroid cancer pathogenesis. Endocrine-Related Cancer, v. 25, n. 2, p. R59-R82, 2018.

NABESHIMA, K. et al. Matrix metalloproteinases in tumor invasion: role for cell migration. Pathology International, v. 52, n. 4, p. 255-264, abr. 2002. 
NAKAMURA, $\mathrm{H}$. et al. Enhanced production and activation of progelatinase $\mathrm{A}$ mediated by membrane-type 1 matrix metalloproteinase in human papillary thyroid carcinomas. Cancer Research, v. 59, n. 2, p. 467-473, 15 jan. 1999.

PAHWA, S.; STAWIKOWSKI, M. J.; FIELDS, G. B. Monitoring and Inhibiting MT1MMP during Cancer Initiation and Progression. Cancers, v. 6, n. 1, p. 416-435, 17 fev. 2014.

PAOLILLO, M.; SCHINELLI, S. Extracellular Matrix Alterations in Metastatic Processes. International Journal of Molecular Sciences, v. 20, n. 19, 7 out. 2019.

PATEL, A. et al. Matrix metalloproteinase (MMP) expression by differentiated thyroid carcinoma of children and adolescents. Journal of Endocrinological Investigation, v. 25, n. 5, p. 403-408, 1 maio 2002.

POWE, D. G. et al. TIMP-3 mRNA expression is regionally increased in moderately and poorly differentiated colorectal adenocarcinoma. British Journal of Cancer, v. 75, n. 11, p. 1678-1683, 1997.

RAJABI, S. et al. The roles and role-players in thyroid cancer angiogenesis. Endocrine Journal, v. 66, n. 4, p. 277-293, 25 abr. 2019.

ROSENTHAL, E. L.; MATRISIAN, L. M. MATRIX METALLOPROTEASES IN HEAD AND NECK CANCER. Head \& neck, v. 28, n. 7, p. 639-648, jul. 2006.

ROY, R. et al. Metalloproteinases and their roles in human cancer. The Anatomical Record, v. 303, n. 6, p. 1557-1572, 2020.

ROZARIO, T.; DESIMONE, D. W. The extracellular matrix in development and morphogenesis: a dynamic view. Developmental Biology, v. 341, n. 1, p. 126-140, 1 maio 2010.

SAFFAR, $\mathrm{H}$. et al. Evaluation of MMP2 and Caspase-3 expression in 107 cases of papillary thyroid carcinoma and its association with prognostic factors. Pathology, Research and Practice, v. 209, n. 3, p. 195-199, mar. 2013.

SARKAR, S. et al. Cancer Development, Progression, and Therapy: An Epigenetic Overview. International Journal of Molecular Sciences, v. 14, n. 10, p. 2108721113, 21 out. 2013.

SEIKI, M. Membrane-type 1 matrix metalloproteinase: a key enzyme for tumor invasion. Cancer Letters, v. 194, n. 1, p. 1-11, 8 maio 2003.

SHAKIB, $H$. et al. Epithelial-to-mesenchymal transition in thyroid cancer: a comprehensive review. Endocrine, v. 66, n. 3, p. 435-455, 2019.

SHI, X. et al. Differential Clinicopathological Risk and Prognosis of Major Papillary Thyroid Cancer Variants. The Journal of Clinical Endocrinology and Metabolism, v. 101, n. 1, p. 264-274, jan. 2016.

SHI, Y. et al. Serum MMP-2 as a potential predictive marker for papillary thyroid carcinoma. PloS One, v. 13, n. 6, p. e0198896, 2018. 
SHIOMI, T.; OKADA, Y. MT1-MMP and MMP-7 in invasion and metastasis of human cancers. Cancer and Metastasis Reviews, v. 22, n. 2, p. 145-152, 1 jun. 2003.

STAMENKOVIC, I. Matrix metalloproteinases in tumor invasion and metastasis. Seminars in Cancer Biology, v. 10, n. 6, p. 415-433, dez. 2000.

STERNLICHT, M. D.; WERB, Z. HOW MATRIX METALLOPROTEINASES REGULATE CELL BEHAVIOR. Annual review of cell and developmental biology, v. 17, p. $463-516,2001$.

TÊTU, B. et al. The influence of MMP-14, TIMP-2 and MMP-2 expression on breast cancer prognosis. Breast Cancer Research, v. 8, n. 3, p. R28, 15 jun. 2006.

TRAN, B. et al. The Prognostic Impact of Tumor Size in Papillary Thyroid Carcinoma is Modified by Age. Thyroid, v. 28, n. 8, p. 991-996, 19 jun. 2018.

TSURUDA, T.; COSTELLO-BOERRIGTER, L. C.; BURNETT, J. C. Matrix metalloproteinases: pathways of induction by bioactive molecules. Heart Failure Reviews, v. 9, n. 1, p. 53-61, jan. 2004.

VALVO, V.; NUCERA, C. Coding molecular determinants of thyroid cancer development and progression. Endocrinology and metabolism clinics of North America, v. 48, n. 1, p. 37-59, mar. 2019.

VASKO, V. et al. Gene expression and functional evidence of epithelial-tomesenchymal transition in papillary thyroid carcinoma invasion. Proceedings of the National Academy of Sciences of the United States of America, v. 104, n. 8, p. 2803-2808, 20 fev. 2007.

VERMA, S.; DIXIT, R.; PANDEY, K. C. Cysteine Proteases: Modes of Activation and Future Prospects as Pharmacological Targets. Frontiers in Pharmacology, v. 7, 25 abr. 2016.

VISSE, R.; NAGASE, $H$. Matrix metalloproteinases and tissue inhibitors of metalloproteinases: structure, function, and biochemistry. Circulation Research, v. 92, n. 8, p. 827-839, 2 maio 2003.

VOULGARI, A.; PINTZAS, A. Epithelial-mesenchymal transition in cancer metastasis: mechanisms, markers and strategies to overcome drug resistance in the clinic. Biochimica Et Biophysica Acta, v. 1796, n. 2, p. 75-90, dez. 2009.

VUONG, H. G. et al. Prognostic implication of BRAF and TERT promoter mutation combination in papillary thyroid carcinoma-A meta-analysis. Clinical Endocrinology, v. 87, n. 5, p. 411-417, 2017.

WALKER, C.; MOJARES, E.; DEL RÍO HERNÁNDEZ, A. Role of Extracellular Matrix in Development and Cancer Progression. International Journal of Molecular Sciences, v. 19, n. 10, 4 out. 2018.

WANG, $\mathrm{H}$. et al. Matrix metalloproteinase-14 expression and its prognostic value in cervical carcinoma. Cell Biochemistry and Biophysics, v. 70, n. 2, p. 729-734, nov. $2014 a$. 
WANG, W. et al. TIMP2 is a Poor Prognostic Factor and Predicts Metastatic Biological Behavior in Gastric Cancer. Scientific Reports, v. 8, n. 1, p. 9629, 25 jun. 2018.

WANG, Y.-Z. et al. MMP-14 overexpression correlates with poor prognosis in nonsmall cell lung cancer. Tumour Biology: The Journal of the International Society for Oncodevelopmental Biology and Medicine, v. 35, n. 10, p. 9815-9821, out. 2014b.

YEH, M. W. et al. Differentiated thyroid cancer cell invasion is regulated through epidermal growth factor receptor-dependent activation of matrix metalloproteinase (MMP)-2/gelatinase A. Endocrine-Related Cancer, v. 13, n. 4, p. 1173-1183, dez. 2006.

YOSHIZAKI, T. et al. Increased expression of membrane type 1-matrix metalloproteinase in head and neck carcinoma. Cancer, v. 79, n. 1, p. 139-144, 1 jan. 1997.

ZEDENIUS, J. et al. Stromal fibroblasts adjacent to invasive thyroid tumors: expression of gelatinase A but not stromelysin 3 mRNA. World Journal of Surgery, v. 20, n. 1, p. 101-106, jan. 1996.

ZHANG, Z. et al. MMP-11 promotes papillary thyroid cell proliferation and invasion via the NF-kB pathway. Journal of Cellular Biochemistry, 1 set. 2018.

$\mathrm{ZHI}$, J. et al. Assessment of the prognostic value and $\mathrm{N} 1 \mathrm{~b}$ changes of the eighth TNM/AJCC staging system for differentiated thyroid carcinoma. International Journal of Clinical Oncology, v. 25, n. 1, p. 59-66, 1 jan. 2020. 


\section{ANEXO A-REAGENTES E SOLUÇÕES}

\section{- $\quad$ PBS $0,1 \mathrm{M}$ pH 7,4}

Foram dissolvidos $16,34 \mathrm{~g}$ de $\mathrm{NaCL}, 0,72 \mathrm{~g}$ de fosfato de sódio monobásico, $2,1 \mathrm{~g}$ de fosfato de sódio dibásico e completado para um volume final de 2 litros com água destilada. $\mathrm{O} \mathrm{pH}$ foi ajustado para 7,4 com $\mathrm{NaOH} 2 \mathrm{M}$.

\section{- Solução de Albumina Bovina (BSA)}

A solução foi preparada com $1 \mathrm{~g}$ de BSA em 1 litro de PBS.

\section{- Solução de Ácido Cítrico}

Foram dissolvidos 2,1 g de ácido cítrico em 1 litro de água destilada. $\mathrm{O} \mathrm{pH}(6,0)$ da solução foi acertado com $\mathrm{NaCl}$.

\section{- Hematoxilina de Harris}

Em um balão volumétrico foram misturados $1000 \mathrm{~mL}$ de água destilada quente e $5 \mathrm{~g}$ de cristais de hematoxilina dissolvidos em $50 \mathrm{~mL}$ de álcool absoluto. Deixamos ferver por 1 minuto. O balão foi removido do fogo e acrescentado 2,5 g de óxido vermelho de mercúrio. Em seguida, o balão foi novamente levado ao fogo até a solução tornar-se cor púrpura escura.

\section{- ÁcidoFosfomolibdico}

Foram dissolvidos $2 \mathrm{~g}$ de ácido fosfomolibdico em $100 \mathrm{~mL}$ de água destilada.

- HCL $0,01 \mathrm{~N}$

Foi diluído $1 \mathrm{~mL}$ de HCL $1 \mathrm{~N}$ em $100 \mathrm{~mL}$ de água destilada.

\section{- Vermelho da Síria (Sirius Red)}

Foi misturado $0,1 \mathrm{~g}$ de vermelho da Síria em $100 \mathrm{~mL}$ de solução de ácido pícrico. 


\section{ANEXO B- PARECER DO COMITÊ DE ÉTICA}

USP - HOSPITAL DAS
CLINICAS DA FACULDADE DE
MEDICINA DE RIBEIRÃO
PRETO DA USP -

\section{PARECER CONSUBSTANCIADO DO CEP}

\section{DADOS DO PROJETO DE PESQUISA}

Titulo da Pesquisa: RELAÇĀO ENTRE A EXPRESSÃo PROTEICA DE MT1-MMP, MMP-2 E TIMP-2 E A PROGRESSĀO DO CARCINOMA PAPILIFERO DE TIREÓIDE.

Pesquisador: VANESSA ALMEIDA AMORIN

Área Temática:

Versalo: 1

CAAE: 25060819.70000 .5440

Instituiç̧o Proponente: UNIVERSIDADE DE SAO PAULO

Patrocinador Principal: Financiamento Prdprio

\section{DADOS DO PARECER}

Número do Parocer: 3.774 .499

Apresentaça do Projoto:

Trata-se de projeto de doutorado de Vanessa Ameida Amorin - Departamento de Patologla e Medicina Legal, Faculdade de Medidina de Ribeirato Preto (FMPP), USP. Campus Robeira Preto sob arientaçso do Prat. Dr. Edson Garcia Sosres do Departamento Patologia e Medicina Legal, Faculdade de Medicina de Rbeirso Preto (FMRP), USP - Campus fobeira Preto com a colaboraçaso de Janaina Regina Lellis do Departamento de Patologia, Faculdade de Medicina de Ribeirao Preto, Universidade de SSo Paulo.

\section{Resumo:}

O carcinoma papilifero da tirebide (CPT) é o carcinoma tireoidiano mais comum, responsável por aproximadamente $80 \%$ de todos os tumares malignos da tiredide. O CPT e propenso a se espalhar pelos ductos linfasicos, resultando em recorrencia, metastases e ate morte. Com isso, as modificaçoes nas metaloproteinases da matriz (MMPs) desempenham um papel principal em varios canceres humanos e podem estar envolvidas na

dferencisça, morfogenese e remodelamento tedidual durante a progressso do carcinama. Algumas MMPs salo anarmalmente expressas no CPT e podem ser usadas como marcadores de diagnostico. As MMPs do tipo membrana (MT-MMPs), um subconjunto de MMPs, nâo salo secretadas, permanecendo aderidas à superticie da celula. Sabe-se que uma das funçóes criticas

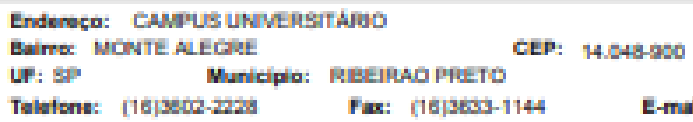




USP - HOSPITAL DAS
CLINICAS DA FACULDADE DE Q ploboformo
MEDICINA DE RIBEIRÃO
PRETO DA USP -

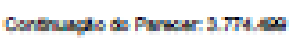

da MT1-MMP e a ativaç5o da MMP-2 e consequente aumento da proteolise da matriz extraceiular. Aseim, uma molecula de MT1-MMP atua como uma ancora e se llga ao TIMP2, que recruta a pro-MMP2 formando um complexo trimolecular: MT1-MMP / TIMP2 / pro-MMP2. Uma segunda molecula MT1-MMP atus como attvador e clva a pro-1MMP2 primeiro em sua forma intermedaria (64 kDa) e depois em sua forma totaimente

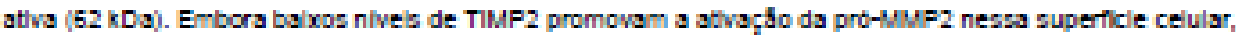
altos nivela de TIMP impedem esse processo de ativaç5o inlbindo a segunda molecula de MT1- MMP. Azsim, a exprezabo de MT1-MMF e a ativaçbo de MMF-2 foram correlaclonadas com o prognoatico em portadores de neoplasias e padrbes de exprezsßes gênicas das duas proteases tambem foram demonatradoa como intenasmente correlatoa. Estudos relataram que o carcinoma paplar superexpresas a MMP2 e sugerem um papel importante para essa enzima na progresabo do carcinoma papllar. Com laso, 0 presente eatudo tem o objetivo de identficar e caracterizar a expresa5o imunolatoquimica da MT1-MMP, MMP-2 e TIMP-2 no microamblente tumoral de paclentes com carcinoma papliffero de tireolde e correlaciond-ia com a progresabo da doença e os dados clinicos e hlstopatologlcos de Importancla prognostca, uma vez que, entender os mecanlemos molecularea do CeT pode ser utll na ldentuficą̧b de novos alvos terapbuticos.

\section{Objotho da Pecquica:}

Objettvo Primario:

Avalar a erprezaso e a localizaç\$o da MT1-MMP, MMP-2 e TIMP-2 em carcinomas papliferos de treolde (CPT) utilzando Imunolatoquimica, bem como as possivels associap̧bes entre a expressbo desses marcadores e os aspectos clinicos e patologicos dos tumores.

Objettivo Secundario:

Caracterizar a expressto e a localizaçbo imunolstoquimica da MT1-MMP, MMP-2 e TIMP-2 no ambiente microtumoral metastatico e nbo metastatico.Correlaclonar a casulatica com os achados clinicos e histopatologicos para elucidaçbo da invas5o e dsseminaçbo das ctluas tumorals no carcinoma paplifero da tireolde. Avallar o potenclal prognoatico dos marcadores MT1-MMP, MMP-2 e TIMP-2 no carcinoma paplitero de tireolde.

\section{Avallaģso doc Ricoce o Bonefloloc:}

Riscos:

A elaboraç5o do presente projeto n\$o apresentara riscos nem aos pesquladores envolvidos nem ao material dos pacientes.

Beneflicios:

Endenço: CAMEUS UNMERertanoo

Batro: MONTE ALECle

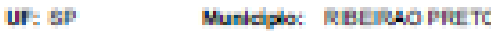

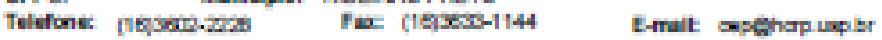




USP - HOSPITAL DAS
CLINICAS DA FACULDADE DE Slotoformo
MEDICINA DE RIBEIRÃO
PRETO DA USP -

Conthuaglo de Parsear: 277.00

Com este eatudo visamos contribuir para o melhor entendimento da invasfo de celulas tumorals atraves de enzimas proteoliticas e avalar o potencla' prognoatico dos marcadores MT1-MMP, MMP-2 e TIMP-2 no carcinoma paplitero de tireolde.

\section{Comentarloc e Concldersp̧oec cobre a Pecquica: \\ Metodologla Proposta: \\ Casulstica}

Sera felta uma andise retrospectiva de 30 casos de neoplasia mallgna da gisindula tireolde tratados cirurglcamente no HC-FMRP (USP) durante o periodo de 2002 a 2015 . Todos os paclentes submetidos a cirurgla aseinaram o Termo de Consentimento LWre e Eaciarecido (TCLE) que permite a utlizaç5o de todos os dados clinicos e patologlcos que conatem em seu prontuario, resguardando-se o slglo sobre a sus Identidade. As liminas arqulvadas coradas por hematoxilina-eosina (HE) serfo reavalladas pelo patologista responstvel para certifcar o dlagnostico e zelecionar as bibpalas com a area de lesto mals representativa. Posteriormente, nova reviabo sera felta pelo patologlata reaponsavel e serbo escolhidos os blocos correspondentes as ISminas mals representativas de lesto como corte com malores dimenades, malores graus de atiplas e amostragem representativa de parbnouima treoldlano ao redor. As informaçbes cinicopatologlcas tals como ldade, sexo, tamanho do tumor, presença de metastase e cbito ser\$o coletados dos prontuarios do Hospltal das CIricas da FMRP. Dados demograflcos, tals como sexo, falya-etarla, cor, estado geral de saude, classe e grupos socials, n5o representarbo criterios de exclusfo ou de inclusto. -

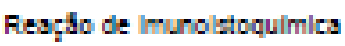

Para essa andlise, serbo utllizados cortes com espessura de $5 \mathrm{~m}$ foram nas amostras parafinadas selecionadas, as quas serfo colocadas em laminas de vidro previamente sinalzadas com organoslano $4 \%$ em acetona e submetidos a tecrica de imunolstoquimica para marcaç5o das proteinas MT1-MMP, MMP-2 e TIMP-2 pelo metodo de avidina-biotna-peroxidase, seguindo as recomendap̧bes do fabricante do kt. Os cortea zerbo desparafnadoa em xilol, reidratados em uma bateria de alcool com concentraçbo decreacente e lavados em agus. A reaç5o sera desenvolvida utilzando recuperaç5o antigênica em panela de pressto durante 35 minutos a $95^{\circ} \mathrm{C}$, com tampSo citrato $10 \mathrm{mM}$ e pH 6,0 . O bioquelo das peroxidases endogenas serd realzada com agua orlgenada a $3 \%$ em PBS por 20 minutos. As llgagbes inespecificas aerbo bloqueadas com aoro nomal de cavalo dluuldo em PBS na concentraça 1:50 num periodo de 30 minutos. Na sequêncla, as ISminas serdo lavadas com FBS e incubsdas com os anticorpce primarioa. Posteriormente serb́o utlizados anticorpos secundarioe con/ugados com estreptavidina-blotina-perovidase por 30 minutos e

Endenço: CAMUS uNMERertauto

Batro MCNTE ALCER

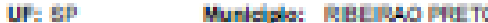

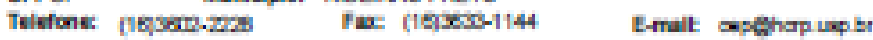

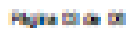




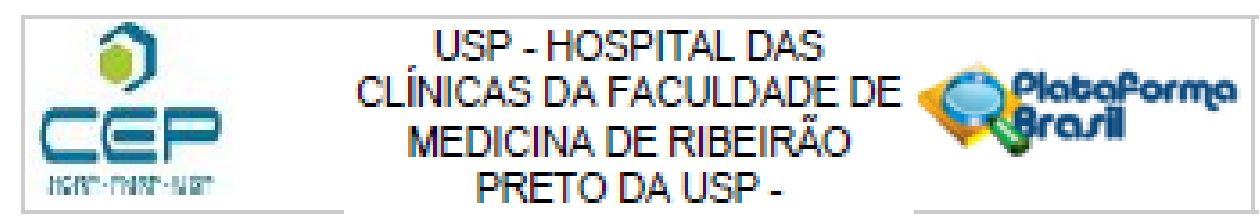

Conthugdo de Parsear: 2 mites

como revelador sera utlizado o DAB (3,3- laminobenzidine) por 30 segundoa. A contra coloraçlo sera feita com hematoxlina de Carazz por 2 minutos e apos a reldrataç5o dos cortes em soluçbes de alcool absoluto e vilol as is minas serfo montadas. Para as reaçbes das proteinas analsadas, serbo utlizados controles extemos positivo e negativo. As Idminas serbo analisadas em microscoplo de luz convencional.

-Analles das celulas imunomarcadas.

Apos a realizaço do metodo imunolstoquimico, as isminas serfo analsadas no microscbplo de luz sob aumentos de $40 x$ e $100 x$. Sera veriflcado a presença ou ausbncla de marcaç5o, alem da intensidade de marcaç5o sendo atrbuldos escores 0 para austrncla de marcaç\$o, escore 1 para fraca marcaç\$o, escore 2

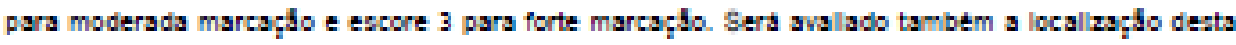
marcaçbo nas celulas

indeleo, choplasma ou trasmembranar.

Crizerio de inclusto:

So serfo inciuldos os pacientes cujos dados clinicos eatho presentes em seus prontusrios medicos e os especimes cirùrgicos dispontvels e concervados para a realizaçbo da imunolatoquimica. O fato do paclente nbo ter perdido o segumento ate o momento da seieçbo do caso tambem serd um fator de inclusbo.

Criterio de Evclus5o:

Ser5o excluldas do estudo amostras com presença de autollse, artefatos ou sinals de processamento Inadequadoa. Blopslas de pacientes com descripjo no prontuario mbdico de sorologla positiva para o HV ou qualquer condlçto organica relacionada com imunoseupressbo ou com historia previa de radloterapla para tratamento de neoplasias tambem serfo excluidas do estudo.

Conclderagoec cobre oc Termec de aprecentaģso obrigatorla:

Documentos avalisdos:

- Folna de Rocto: devidamente presenchida e aseinada

- Formultrio UPC: devidamente presnchido e asainsdo

- Orçamento: custos TOTAL de R\$ 7.353,07 de responsabilidade do pesoulasdor responative;

- Cronogramar realizado em 1 ano.

- Projeto de pezoulas

- Termo de Consentimento Lvre e Exclarecido

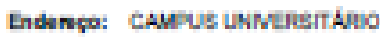

Batro: MONTE ALCER:

Uf: sp Murialolo: ReERao Meto

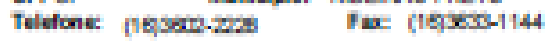

CEP: 14045000

E-malt aschapuspt

Hen be os o 


\section{USP - HOSPITAL DAS
CLINICAS DA FACULDADE DE
MEDICINA DE RIBEIRÃO
Plotoformo
PRETO DA USP -}

Continuaplo do Parke: 2774.400

Recomendaç6es:

Nso hat.

Conclusóes ou Pendénclas e Lista de Inadequaçoes:

Diante do exposto e a luz da Resoluçso CNS 465/2012, o projeto de pesquisa, assim como a solicitaça de dispensa do Termo de Consentimento Livre e Esclarecido, podem ser enquadrados na categoria APRONADO.

\section{Consideraçóes Finais a critério do CEP:}

Projeto Aprovada: Tendo em vista a legislaçăo vigente, devem ser encaminhados ao CEP, relattorios parciais anuais referentes ao andamento da pesquisa e relatbrio final ao termino do trabalho. Qualquer modificaçalo do projeto original deve ser apresentada a este CEP em nova versbo, de forma objetiva e com justificativas, para nowa aprecisçso.

Este parecer fol elaborado baseado nos documentos abalwo rolacionados:

\begin{tabular}{|c|c|c|c|c|}
\hline Tipo Documento & Arquivo & Postagem & Autor & Stuaçalo \\
\hline $\begin{array}{l}\text { Informaçóes Bdsicas } \\
\text { do Projefo }\end{array}$ & $\begin{array}{l}\text { PB_INFCRMACOCES_BASICAS_DO_P } \\
\text { ROJETO 1448S42 pdt }\end{array}$ & $\begin{array}{c}D E / 11 / 2019 \\
18.2402\end{array}$ & & Aceto \\
\hline $\begin{array}{l}\text { TCLE / Termos de } \\
\text { Assentimento f } \\
\text { Justificativa de } \\
\text { Austencis. }\end{array}$ & trielepdf & $\begin{array}{c}06 / 11 / 2019 \\
18: 23: 28\end{array}$ & $\begin{array}{l}\text { VANESSA ALMEIDA } \\
\text { AMORIN }\end{array}$ & Aceto \\
\hline $\begin{array}{l}\text { Projefo Detahado I } \\
\text { Brochura } \\
\text { Imvertiasdor }\end{array}$ & PRODETO.pdf & $\begin{array}{c}01 / 11 / 2019 \\
10: 2824\end{array}$ & $\begin{array}{l}\text { VANESSA ALMEIDA } \\
\text { AMORIN }\end{array}$ & Aceto \\
\hline Orçamento & upc.pdf & $\begin{array}{l}01 / 11 / 2019 \\
10: 26: 28\end{array}$ & $\begin{array}{l}\text { VANESSA ALMEIDA } \\
\text { AMORIN }\end{array}$ & Acelto \\
\hline Folha de Rosto & folha.pdf & $\begin{array}{c}01 / 11 / 2019 \\
10: 24: 39\end{array}$ & $\begin{array}{l}\text { VANESSA ALMEIDA } \\
\text { AMORIN }\end{array}$ & Aceito \\
\hline
\end{tabular}

\section{Situaçato do Parecer:}

Aprovado

Necessita Apreciaça da CONEP:

Năo

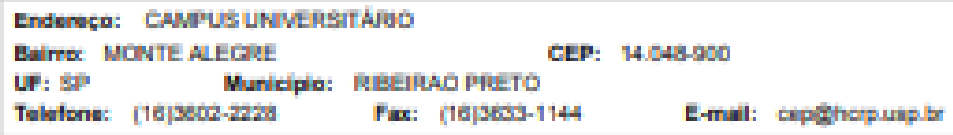




USP - HOSPITAL DAS
CLINICAS DA FACULDADE DE Q Plotoformo
MEDICINA DE RIBEIRÄO
PRETO DA USP -

Conthuaglo de Parsear 277.00

RIgEIRAO FRETO, 16 de Dezembro de 2019

Acelnado por:

UARCIA GUIUARAES VILLANONA

[Coordensdor[a)]

Endenço: CAMEUS unmefest Auto

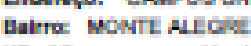

CEP: 14.045900

Ur: SP Muridiplo: ReERea MALTO

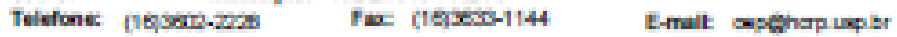

